\title{
A conformational and vibrational study of $\mathrm{CF}_{3} \mathrm{COSCH}_{2} \mathrm{CH}_{3}$
}

\author{
María Eliana Defonsi Lestard, ${ }^{1}$ María Eugenia Tuttolomondo, ${ }^{1}$ Derek A. Wann, ${ }^{2}$ \\ Heather E. Robertson, ${ }^{2}$ David W. H. Rankin, ${ }^{2}$ and Aida Ben Altabef ${ }^{1, a)}$ \\ ${ }^{1}$ Instituto de Química del Noroeste Argentino (INQUINOA), Consejo Nacional de Investigaciones Científicas \\ y Técnicas (CONICET), Argentina and Instituto de Química Física, Facultad de Bioquímica, Química \\ y Farmacia, Universidad Nacional de Tucumán, San Lorenzo 456, T4000CAN Tucumán, Argentina \\ ${ }^{2}$ School of Chemistry, University of Edinburgh, West Mains Road, Edinburgh EH9 3JJ, United Kingdom
}

(Received 22 July 2009; accepted 4 November 2009; published online 3 December 2009)

\begin{abstract}
The molecular structure and conformational properties of $S$-ethyl trifluorothioacetate, $\mathrm{CF}_{3} \mathrm{COSCH}_{2} \mathrm{CH}_{3}$, were determined in the gas phase by electron diffraction and vibrational spectroscopy (IR and Raman). The experimental investigations were supplemented by ab initio (Møller Plesset of second order) and density functional theory quantum chemical calculations at different levels of theory. Both experimental and theoretical methods reveal two structures with $C_{s}$ (anti, anti) and $C_{1}$ (anti, gauche) symmetries, although there are disagreements about which is more stable. The electron diffraction intensities are best interpreted with a mixture of 51(3)\% anti, anti and $49(3) \%$ anti, gauche conformers. This conformational preference was studied using the total energy scheme and the natural bond orbital scheme. In addition, the infrared spectra of $\mathrm{CF}_{3} \mathrm{COSCH}_{2} \mathrm{CH}_{3}$ are reported for the gas, liquid and solid phases as well as the Raman spectrum of the liquid. Using calculated frequencies as a guide, evidence for both $C_{s}$ and $C_{1}$ structures is obtained in the IR spectra. Harmonic vibrational frequencies and scaled force fields have been calculated for both conformers. (C) 2009 American Institute of Physics. [doi:10.1063/1.3267633]
\end{abstract}

\section{INTRODUCTION}

$S$-ethyl trifluorothioacetate, $\mathrm{CF}_{3} \mathrm{COSCH}_{2} \mathrm{CH}_{3}$, is a trifluoroacetylating agent used to provide an amine-protecting group. ${ }^{1}$ The intense electrophilic nature of the trifluoroacyl group combined with the unusual aminophilicity of the sulfur atom makes it ideal for use in peptide syntheses. ${ }^{2}$ Thioesters such as $\mathrm{CF}_{3} \mathrm{COSCH}_{2} \mathrm{CH}_{3}$ are also important components of coenzyme A, which plays an essential role in metabolism. The microwave spectra of several ethyl thioesters were reported by True et al. in $1981{ }^{3}$ though notably they determined the existence of only one stable conformer of the title molecule.

Our previous studies of various esters of trifluoroacetic acid with the general formula $\mathrm{CF}_{3} \mathrm{CO}_{2} \mathrm{R}$ (Refs. 4-6) (R $=\mathrm{CH}_{3}, \mathrm{CH}_{2} \mathrm{CH}_{3}, \mathrm{CH}_{2} \mathrm{CF}_{3}$ ) have therefore been extended to include the related thioester, $\mathrm{CF}_{3} \mathrm{COSCH}_{2} \mathrm{CH}_{3}$, the first of the type $\mathrm{CF}_{3} \mathrm{COXR}$. Although the structural and conformational properties of simple oxoesters and thioesters have been studied by several groups mainly because of the central role of thioesters in the metabolic process, the factors controlling this behavior are far from being understood. This was highlighted in an extensive computational study undertaken by Drueckhammer et $a .^{7}$ The role played by experimental structural studies in understanding the behavior of molecules has been recently discussed, ${ }^{8}$ and gas electron diffraction (GED) has already been used to determine the structures of many $-\mathrm{SC}=\mathrm{O}-$ containing compounds. In addi-

\footnotetext{
${ }^{\text {a) }}$ Author to whom correspondence should be addressed. Tel.: +54-3814311044. FAX: +54-381-4248169. Electronic mail: altabef@fbqf.unt.edu.ar. Member of the Carrera del Investigador Científico, CONICET, Argentina.
}

tion to the early work of Shen and Hagen on $\mathrm{ClC}(\mathrm{O}) \mathrm{SCl},{ }^{9}$ the GED group of Oberhammer et al. reported gas-phase structures for several related species. ${ }^{10-15}$

Here we investigate the characteristic conformations and force constants of $\mathrm{CF}_{3} \mathrm{COSCH}_{2} \mathrm{CH}_{3}$; the comparison of the conformations and geometrical parameters with those of $\mathrm{CF}_{3} \mathrm{CO}_{2} \mathrm{CH}_{2} \mathrm{CH}_{3}$ (Ref. 5) is particularly interesting. We have determined the structure of the molecule using GED, and additionally, infrared and Raman spectra have been recorded for different physical states and the molecular structures and vibrational wavenumbers of the different conformers were calculated quantum mechanically. The spectral features were subsequently assigned to the different normal modes of vibration. The study was complemented by natural bond orbital (NBO) analysis to assess the significance of hyperconjugative interactions, which would favor one conformation over another.

\section{EXPERIMENTAL}

Samples of $\mathrm{CF}_{3} \mathrm{COSCH}_{2} \mathrm{CH}_{3}$ for use in both electron diffraction and spectroscopy experiments were purchased from Sigma-Aldrich and used without further purification. All handling was performed under dry nitrogen to protect the samples from atmospheric humidity.

\section{A. Infrared and raman spectroscopy}

Infrared spectra for $\mathrm{CF}_{3} \mathrm{COSCH}_{2} \mathrm{CH}_{3}$ in the liquid and solid phases were recorded in the $4000-400 \mathrm{~cm}^{-1}$ range at room temperature using a Perkin-Elmer GX1 Fourier transform infrared instrument. A glass cell with a $10 \mathrm{~cm}$ optical path and $\mathrm{Si}$ windows was used to obtain the gas-phase spec- 
tra. The spectrum for the solid was obtained after depositing the compound from the vacuum line onto a $\mathrm{KBr}$ window, maintained at about $197 \mathrm{~K}$, in a variable temperature RIIC (VLT-2) cell. Raman spectra of the liquid at room temperature, polarized at $0^{\circ}$ and $90^{\circ}$, were obtained with a Fourier Transform-Raman RFS 100/S spectrometer using 1064 nm light from an Nd-YAG (Neodymium-doped yttrium aluminum garnet) laser for excitation.

\section{B. GED}

Data were collected for $\mathrm{CF}_{3} \mathrm{COSCH}_{2} \mathrm{CH}_{3}$ on Kodak Electron Image films using the Edinburgh GED apparatus. ${ }^{16}$ The accelerating voltage was held at approximately $40 \mathrm{keV}$, yielding electrons with a wavelength of approximately $6 \mathrm{pm}$. Data were collected at two nozzle-to-film distances to increase the range of angles over which scattering was observed. The nozzle was at room temperature (approximately $293 \mathrm{~K}$ ), while the sample was cooled to $253 \mathrm{~K}$ for both experiments.

The scattering patterns were converted into digital form using an Epson Expression 1680 Pro flatbed scanner and an extraction program described elsewhere. ${ }^{17}$ Data reduction and least-squares refinements were performed using the ED@ED V.3.0 program $^{18}$ employing the scattering factors of Ross et $a{ }^{19}{ }^{19}$ The weighting points for the off-diagonal weight matrices, correlation parameters, and scale factors for both nozzle-to-film distances are given in Table $\mathrm{S} 1{ }^{20}$

\section{Computational details}

Calculations were performed using the resources of the United Kingdom National Service for Computational Chemistry Software (NSCCS), ${ }^{21}$ running the GAUSSIAN 03 suite of programs. $^{22}$ Potential-energy curves were calculated at the MP2, mPW1PW91, and B3LYP levels using the 6-31G(d), 6-311G(d,p), and 6-311++G(d,p) basis sets, as well as using the B3LYP/6-311G(3df,3dp) combination, and two minima were identified by rotating about the $\mathrm{S}-\mathrm{C}\left(\mathrm{H}_{2}\right)$ bond. All calculations were performed in such a way that only the given torsion was fixed and all other parameters were allowed to relax. The total energy curve was constructed in steps of $5^{\circ}$ or $10^{\circ}$ using default convergence criteria as implemented in GAUSSIAN $03 .^{22}$

The minima related to one $C_{s}$-symmetric structure and one with $C_{1}$ symmetry. The difference in total energy between the two minima was small. The calculations showed that only structures with staggered $\mathrm{CH}_{3}$ and $\mathrm{CF}_{3}$ groups were real.

Geometry optimizations were performed for both conformers at the MP2 (Ref. 23) and density functional theory (DFT) methods with the 6-311G(d), ${ }^{24} 6-311 \mathrm{G}(3 \mathrm{df}, 3 \mathrm{pd}),{ }^{25-27}$ and $6-311++G(d, p)$ (Ref. 28) basis sets. One of the DFT methods used Becke's B3 (Ref. 18) hybrid exchange functional and the Lee-Yang-Parr nonlocal correlation functional (LYP). ${ }^{29}$ The second DFT method was mPW1PW91, which used a modified Perdew-Wang exchange functional and Perdew-Wang 91 correlation functional. ${ }^{30}$ All calculations were spin-restricted and frozen-core. At the B3LYP/6-311 $++\mathrm{G}(\mathrm{d}, \mathrm{p})$ level, the free energies of the two conformers were calculated, showing that the $C_{s}$-symmetric conformer was lower in energy than the $C_{1}$ conformer by approximately $2.6 \mathrm{~kJ} \mathrm{~mol}^{-1}$.

Vibrational frequencies were calculated from analytic second derivatives to check that optimized structures represented minima on the potential-energy surface. Force constants calculated at the B3LYP/6-311++G(d,p) level were subsequently used, along with the program SHRINK, ${ }^{31}$ to obtain initial amplitudes of vibration and also to calculate curvilinear distance correction terms for use in the GED refinement. The structure obtained from the refinement is therefore of the type $r_{\mathrm{h} 1}$. A NBO calculation was performed at the B3LYP/6-311++G(d,p) level using the NBO $3.0 \operatorname{code}^{32}$ as implemented in the GAUSSIAN 03 package. $^{22}$

A harmonic force field in Cartesian coordinates calculated at the B3LYP/6-311++G(d,p) level was transformed to a set of natural internal (local symmetry) coordinates ${ }^{33}$ via the $\mathrm{B}$ matrix ${ }^{34}$ using a standard program. The scaled quantum mechanical (SQM) force field was obtained using the scheme outlined by Pulay et al., ${ }^{35}$ in which the diagonal force constants are multiplied by scale factors $f_{i}, f_{j}, \ldots$, and the corresponding interaction constants are multiplied by $\left(f_{i} f_{j}\right)^{1 / 2}$, thus adjusting the scale factors to reproduce the experimental frequencies as well as possible. An initial set of scale factors was refined to fit the calculated frequencies to the experimental data. No empirical correction of the theoretical geometry was used. The potential-energy distribution was then calculated with the resulting SQM force field. The force field for the $C_{s}$ conformation, scaling, and determination of the potential-energy distribution were performed with the program FCARTP. ${ }^{36}$ The atomic displacements given by the GAUSSIAN 03 program for each vibrational mode were used to understand the nature of the molecular vibrations qualitatively, and for that purpose, the corresponding data were represented graphically using the GAUSSVIEW program. $^{37}$

\section{RESULTS AND DISCUSSION}

\section{A. Quantum chemical calculations}

Two stable conformations, with $C_{1}$ (anti, gauche) and $C_{s}$ (anti, anti) symmetries (Fig. 1), were identified with every combination of theory and basis set that was used. In the anti, anti conformation [Fig. 1(b)], the $\mathrm{C}(15) \mathrm{C}(16) \mathrm{S}(28) \mathrm{C}(21)$ and $\mathrm{C}(16) \mathrm{S}(28) \mathrm{C}(21) \mathrm{C}(24)$ dihedral angles are both $180^{\circ}$. In the anti, gauche conformations (two enantiomeric forms), the $\mathrm{C}(1) \mathrm{C}(2) \mathrm{S}(14) \mathrm{C}(7)$ dihedral angles are $180^{\circ}$, while the $\mathrm{C}(2) \mathrm{S}(14) \mathrm{C}(7) \mathrm{C}(10)$ dihedral angle has a gauche value of approximately $+/-80^{\circ}$.

Calculated geometrical parameters for $\mathrm{CF}_{3} \mathrm{COSCH}_{2} \mathrm{CH}_{3}$ are listed in Table I along with parameters from the experimental electron diffraction structure. As was found for the related compound $\mathrm{CH}_{3} \mathrm{SO}_{2} \mathrm{SCH}_{3}$, ${ }^{38}$ the inclusion of extra polarization functions (beyond a single $\mathrm{d}$ function) is necessary to predict the bond lengths in this type of molecule accurately. The parameter most sensitive to this orbital description is the $\mathrm{X}-\mathrm{S}$ bond, which was shortened by $1.4 \mathrm{pm}$. upon replacing the $6-311 \mathrm{G}(\mathrm{d})$ basis set with $6-311 \mathrm{G}(3 \mathrm{df}, 3 \mathrm{pd})$. All bonds involving the sulfur atom were 

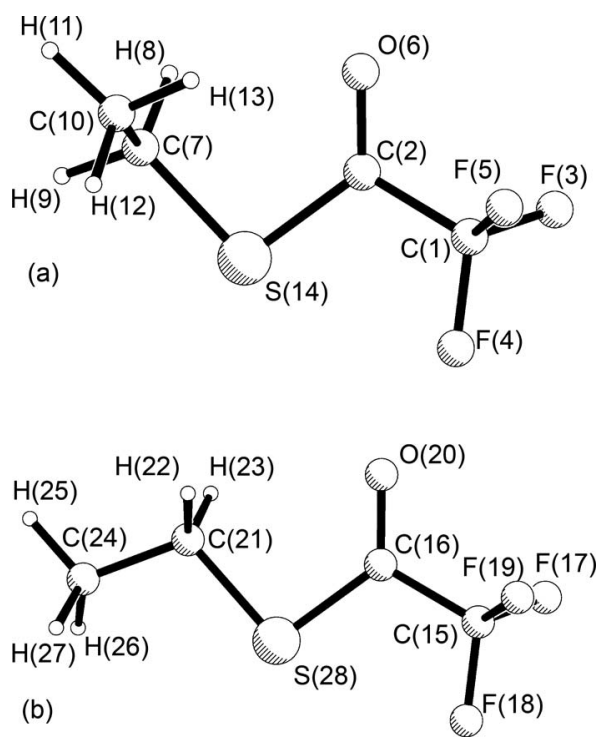

FIG. 1. Molecular structures (including atom numbering used in the GED refinement) of (a) the $C_{1}$ conformer and (b) the $C_{s}$ conformer of $\mathrm{CF}_{3} \mathrm{COSCH}_{2} \mathrm{CH}_{3}$.

shortened by over 1 pm., but the remaining bond lengths were relatively unchanged. An additional geometry optimization was performed with the 6-311G(d) basis on all atoms except the sulfur atom, for which a 6-311G(3df) basis set was used. This produced a geometry close to both the experimental structure and to that calculated using the $6-311 \mathrm{G}(3 \mathrm{df}, 3 \mathrm{pd})$ basis set, demonstrating that only the polarization of the basis set on sulfur is critical for obtaining accurate bond lengths in these types of structures. (See Table $\mathrm{S} 2$ for the root-mean-square deviations (RMSD) between the GED distances and some calculated ones.) ${ }^{20}$

In 1981 True et $a .^{3}$ measured the barrier to rotation about the $\mathrm{CSCC}$ dihedral angle in $\mathrm{CF}_{3} \mathrm{COSCH}_{2} \mathrm{CH}_{3}$ using microwave spectroscopy. The barrier height was found to be

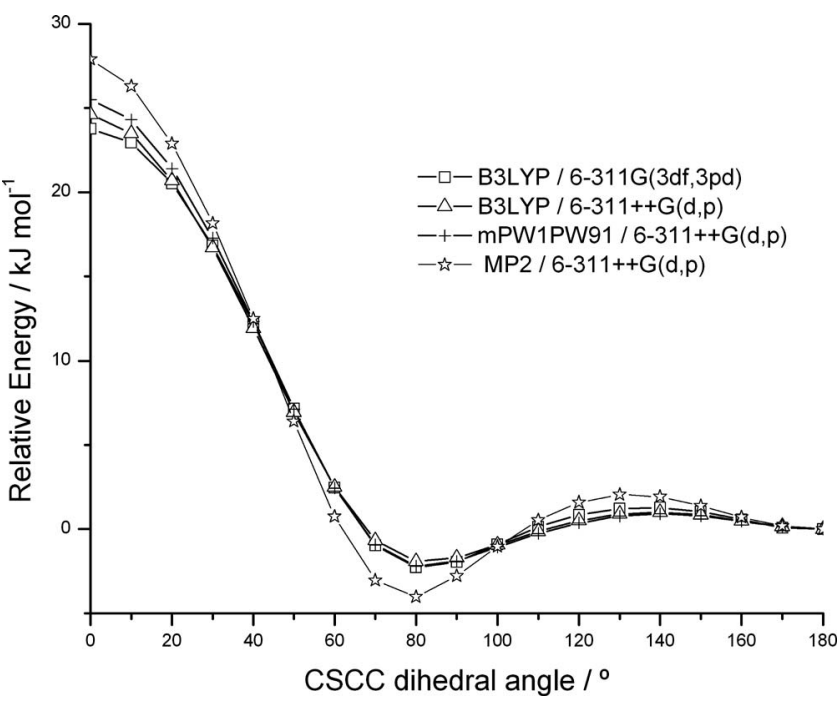

FIG. 2. Torsional potential about the $\mathrm{S}-\mathrm{C}\left(\mathrm{H}_{2}\right)$ bond of $\mathrm{CF}_{3} \mathrm{COSCH}_{2} \mathrm{CH}_{3}$ calculated at MP2, mPW1PW91, and B3LYP levels using the 6-311+ $+\mathrm{G}(\mathrm{d}, \mathrm{p})$ basis set.

$5.85 \mathrm{~kJ} \mathrm{~mol}^{-1}$, which differs significantly from the computed results quoted in this work. The same microwave spectroscopic study determined the presence of only one conformer (the anti, gauche structure) rather than the two conformers identified by our calculations and evident in the GED and vibrational spectroscopy results. Studying the nature of the CSCC barrier is extremely interesting as we will be able to find the two conformations reported by GED and the causes of their stability.

The potential-energy scans about the $\mathrm{S}-\mathrm{C}\left(\mathrm{H}_{2}\right)$ bond at the MP2, mPW1PW91, and B3LYP levels using the 6-311 $++\mathrm{G}(\mathrm{d}, \mathrm{p})$ basis set and using the B3LYP/6-311G(3df,3pd) combination are shown in Fig. 2. There is good agreement between methods, identifying two stable forms, one with $C_{1}$ symmetry and another with $C_{s}$ symmetry. The total and rela-

TABLE I. Selected calculated and experimental (GED) geometrical parameters for $\mathrm{CF}_{3} \mathrm{COSCH}_{2} \mathrm{CH}_{3}$ and $\mathrm{CF}_{3} \mathrm{CO}_{2} \mathrm{CH}_{2} \mathrm{CH}_{3}$.

\begin{tabular}{|c|c|c|c|c|c|c|c|c|}
\hline \multirow[b]{3}{*}{ Geometrical parameter $^{\mathrm{b}}$} & \multicolumn{4}{|c|}{$\mathrm{CF}_{3} \mathrm{COSCH}_{2} \mathrm{CH}_{3}$} & \multicolumn{4}{|c|}{$\mathrm{CF}_{3} \mathrm{CO}_{2} \mathrm{CH}_{2} \mathrm{CH}_{3}{ }^{\mathrm{a}}$} \\
\hline & \multicolumn{2}{|c|}{$C_{s}$ conformer } & \multicolumn{2}{|c|}{$C_{1}$ conformer } & \multicolumn{2}{|c|}{$C_{s}$ conformer } & \multicolumn{2}{|c|}{$C_{1}$ conformer } \\
\hline & GED & Calculated $^{\mathrm{c}}$ & GED & Calculated $^{\mathrm{c}}$ & GED & Calculated $^{\mathrm{c}}$ & GED & Calculated $^{\mathrm{c}}$ \\
\hline \multicolumn{9}{|l|}{ Distances } \\
\hline $\mathrm{C}(15)-\mathrm{F}$ mean & 134.0 & 133.8 & 134.0 & 133.7 & 134.4 & 134.2 & 133.8 & 134.2 \\
\hline$C(15)-C(16)$ & 154.6 & 154.6 & 154.6 & 154.6 & 154.5 & 154.3 & 154.6 & 154.4 \\
\hline $\mathrm{C}(16)=\mathrm{O}(20)$ & 121.6 & 121.4 & 121.6 & 121.4 & 121.2 & 120.6 & 121.3 & 120.7 \\
\hline $\mathrm{C}(16)-\mathrm{S} / \mathrm{O}(28)$ & 175.9 & 175.0 & 176.1 & 175.2 & 133.1 & 133.0 & 133.0 & 132.9 \\
\hline $\mathrm{S} / \mathrm{O}(28)-\mathrm{C}(21)$ & 182.7 & 181.5 & 182.6 & 181.5 & 145.4 & 145.1 & 145.6 & 145.5 \\
\hline$C(21)-C(24)$ & 153.3 & 152.6 & 153.2 & 152.5 & 150.8 & 151.2 & 151.2 & 151.6 \\
\hline \multicolumn{9}{|l|}{ Angles } \\
\hline $\mathrm{C}(15)-\mathrm{C}(16)-\mathrm{S} / \mathrm{O}(28)$ & 114.3 & 115.2 & 113.7 & 114.6 & 110.1 & 109.6 & 110.1 & 109.4 \\
\hline $\mathrm{C}(16)-\mathrm{S} / \mathrm{O}(28)-\mathrm{C}(21)$ & 95.9 & 97.4 & 95.9 & 97.6 & 114.6 & 114.7 & 115.1 & 115.4 \\
\hline $\mathrm{S} / \mathrm{O}(28)-\mathrm{C}(21)-\mathrm{C}(24)$ & 111.3 & 109.3 & 115.0 & 112.8 & 104.4 & 106.9 & 109.3 & 110.7 \\
\hline \multicolumn{9}{|l|}{ Dihedral angles } \\
\hline $\mathrm{C}(15)-\mathrm{C}(16)-\mathrm{S} / \mathrm{O}(28)-\mathrm{C}(21)$ & 180.0 & 180.0 & 161.4 & 173.8 & 180.0 & 180.0 & 182.4 & 179.9 \\
\hline $\mathrm{C}(16)-\mathrm{S} / \mathrm{O}(28)-\mathrm{C}(21)-\mathrm{C}(24)$ & 180.0 & 180.0 & -78.0 & -78.4 & 180.0 & 180.0 & 98.7 & 86.0 \\
\hline
\end{tabular}

${ }^{\mathrm{a}}$ Reference 4.

${ }^{\mathrm{b}}$ Distances in picometer and angles in degrees.

${ }^{\mathrm{c}} \mathrm{MP} 2 / 6-311++\mathrm{G}(\mathrm{d}, \mathrm{p})$. 
TABLE II. Free energies (zero-point corrected), differences in free energies (energies in hartrees), and differences in total energies (not zero-point corrected) for two conformers of $\mathrm{CF}_{3} \mathrm{COSCH}_{2} \mathrm{CH}_{3}$ at different levels of theory.

\begin{tabular}{|c|c|c|c|c|c|c|}
\hline Method & Basis set & $G\left(C_{1}\right)$ & $G\left(C_{s}\right)$ & $\begin{array}{c}\Delta E_{\mathrm{T}} \\
\left(\mathrm{kJ} \mathrm{mol}^{-1}\right)\end{array}$ & $\begin{array}{c}\Delta G^{\mathrm{a}} \\
\left(\mathrm{kJ} \mathrm{mol}^{-1}\right)\end{array}$ & $\begin{array}{l}\text { Barrier height } \\
\quad\left(\mathrm{kJ} \mathrm{mol}^{\mathrm{b}}\right)\end{array}$ \\
\hline \multirow[t]{4}{*}{ B3LYP } & $6-31 G(d)$ & -928.31821 & -928.31820 & -1.93 & -0.03 & 25.57 \\
\hline & $6-311 \mathrm{G}(\mathrm{d}, \mathrm{p})$ & -928.50402 & -928.50388 & -2.83 & -0.36 & 26.55 \\
\hline & $6-311 \mathrm{G}(3 \mathrm{df}, 3 \mathrm{dp})$ & -928.55107 & -928.55108 & -2.15 & 0.03 & 23.79 \\
\hline & $6-311++G(d, p)$ & -928.51962 & -928.52061 & -2.07 & 2.60 & 26.52 \\
\hline \multirow[t]{2}{*}{ MP2 } & $6-31 G(d)$ & -926.34679 & -926.34652 & -3.58 & -0.71 & 30.37 \\
\hline & $6-311++\mathrm{G}(\mathrm{d}, \mathrm{p})$ & -926.71674 & -926.71375 & -4.10 & -7.85 & 31.92 \\
\hline \multirow[t]{3}{*}{ mPW1PW91 } & $6-31 G(d)$ & -928.19955 & -928.19952 & -2.03 & -1.15 & 26.88 \\
\hline & $6-311 G(d, p)$ & -928.37432 & -928.37421 & -3.09 & -0.31 & 27.90 \\
\hline & $6-311++G(d, p)$ & -928.38867 & -928.38877 & -2.21 & 0.27 & 27.51 \\
\hline Experimental $^{\mathrm{c}}$ & & & & & & 5.85 \\
\hline
\end{tabular}

${ }^{\mathrm{a}} \Delta G=G\left(C_{1}\right)-G\left(C_{s}\right)$.

${ }^{\mathrm{b}} \Delta G=E_{\mathrm{T}}(T S)-E_{\mathrm{T}}\left(C_{1}\right)$.

${ }^{\mathrm{c}}$ Value from the microwave study in Ref. 3.

tive energies of the conformers given by various calculations are listed in Table II. At the MP2/6-311++G(d,p) level the free energies of the two conformers showed that the $C_{1}$-symmetric conformer was lower in energy than the $C_{s}$ conformer by approximately $7.85 \mathrm{~kJ} \mathrm{~mol}^{-1}$; at the B3LYP/ 6-311++G(d,p) level the corresponding energy difference was $2.60 \mathrm{~kJ} \mathrm{~mol}^{-1}$, with the $C_{s}$ conformer lower in energy. There is therefore significant disagreement as to the composition of the gas-phase sample that should be determined experimentally by GED.

For both of the conformers identified above, the free energy calculated using the B3LYP/6-311++G(d,p) method was used along with the average temperature of the experiment to estimate (using the Boltzmann distribution) the amount of each conformer that should be observed in the gas phase. As the difference in free energy was calculated to be $2.60 \mathrm{~kJ} \mathrm{~mol}^{-1}$ ( $C_{s}$ conformer lower in energy) and as the $C_{1}$ conformer has a double multiplicity relative to the $C_{s}$ conformer, the ratio of $C_{1}$ to $C_{s}$ conformers was predicted to be 0.41:0.59.

In order to investigate the energetic consequences of rotating about the $\mathrm{S}-\mathrm{C}\left(\mathrm{H}_{2}\right)$ bond, the torsional barrier has been characterized using two different schemes. In the first one, the NBO partitioning scheme has been applied in order to decompose the total energy into the $E_{\text {Lewis }}$ and $E_{\text {deloc }}$ terms. In the second one, the total energy changes have been decomposed as a sum of potential and kinetic contributions. MP2/6-311++G(d,p) and B3LYP/6-311++G(d,p) have been selected as representative of the methods used in this work for the energy decomposition as they yield good results for barrier height and molecular geometry, respectively. Because the results from the two methods for the selected levels are similar, we will concentrate our discussion on B3LYP/ 6-311++G(d,p). Plots for HF/6-311++G(d,p) and MP2/6-311++G(d,p) appear as Figures $\mathrm{S} 1$ and $\mathrm{S} 2$, respectively. ${ }^{20}$

\section{B. Contributions of the lewis and delocalization energies to the barrier}

$\mathrm{NBO}$ analysis has frequently been used in the evaluation of the anomeric effect and the origin of the internal rotation barrier. NBO analysis allows us to estimate the energy of the molecule with the same geometry but in the absence of the electronic delocalization. Moreover, only the steric and electrostatic interactions through the term $E_{\text {Lewis }}$ are taken into account. $^{39-42}$

Following this scheme, the energy barrier $\Delta E_{\text {barrier }}$ can be written as a function of bond strength, hyperconjugation, and steric repulsion,

$$
\Delta E_{\text {barrier }}=\Delta E_{\text {Lewis }}+\Delta E_{\text {deloc }}=\Delta E_{\text {struct }}+\Delta E_{\text {exc }}+\Delta E_{\text {deloc }}
$$

where $\Delta E_{\text {struct }}$ takes into account Coulombic and bondenergy changes in the classical structure, $\Delta E_{\text {exc }}$ known as the Pauli exchange (or steric) repulsion energy] accounts for the non-Coulombic energy changes arising from the Pauli exclusion principle, and $\Delta E_{\text {deloc }}$ describes the hyperconjugative stabilization.

Table S3 (Ref. 20) presents the contributions from the localized electron density $\left(E_{\text {Lewis }}\right)$ and the delocalized electron density $\left(E_{\text {deloc }}\right)$ to the rotation barrier about the $\mathrm{S}-\mathrm{C}\left(\mathrm{H}_{2}\right)$ bond at the B3LYP/6-311++G(d,p) level. This table shows that the Lewis energy is decisive for the energetic preference; its minima correspond to the anti, anti and anti, gauche conformers. When electronic delocalization is lacking, the steric effect would be dominant in both conformers but greater in the anti, anti conformer as expected for an anomeric effect of stereoelectronic origin (Fig. 3).

The delocalization energy difference, $\Delta E_{\text {deloc }}$, is greater for the anti, anti conformer than for the anti, gauche conformer. This effect of the anti, gauche structure in $\mathrm{CF}_{3} \mathrm{COSCH}_{2} \mathrm{CH}_{3}$ can be rationalized by orbital interactions between the two sulfur lone pairs (lp $\mathrm{S}$ ) and the vicinal antibonding orbitals. According to an NBO analysis, the anomeric orbital interaction lp $\mathrm{S}(14 / 28)$ $\rightarrow \sigma^{*} \mathrm{C}(7 / 21)-\mathrm{C}(10 / 24)$, which only appears in the anti, gauche form, is $14.92 \mathrm{~kJ} \mathrm{~mol}^{-1}$ (see Table S4). ${ }^{20}$ 


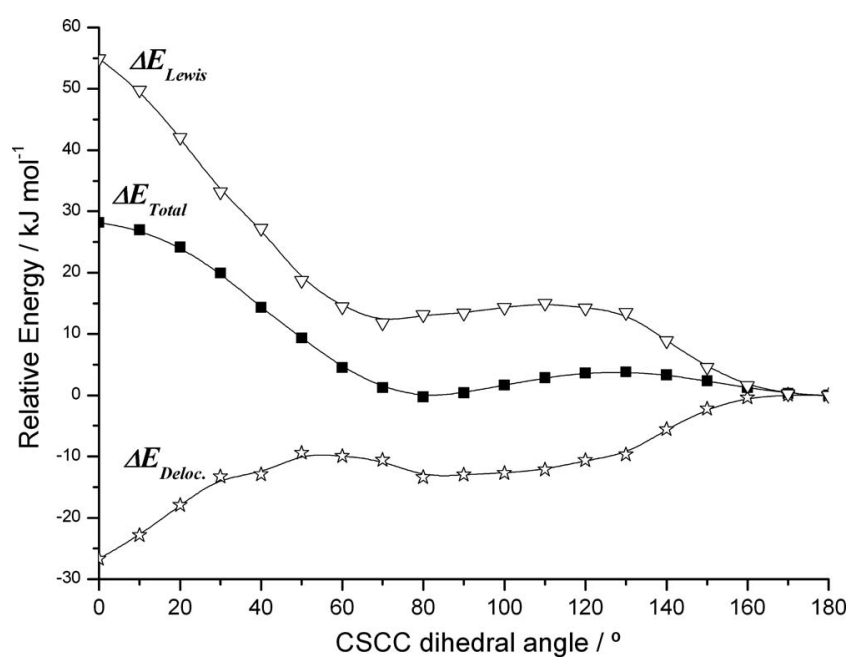

FIG. 3. Dependence of the relative total energy of the $\mathrm{CF}_{3} \mathrm{COSCH}_{2} \mathrm{CH}_{3}$ molecule and its $\Delta E_{\text {Lewis }}$ and $\Delta E_{\text {deloc }}$ parts on the CSCC rotation angle calculated using the B3LYP/6-311++G(d,p) method.

\section{Contribution of different potential-energy terms to the barrier}

In our second approach, we have performed an investigation of the energy barrier based on the partition offered by the scheme,

$$
\Delta E=\Delta E_{\mathrm{nn}}+\Delta E_{\mathrm{en}}+\Delta E_{\mathrm{ee}}+\Delta E_{\mathrm{k}},
$$

where $\Delta E$ is the total energy change between structures of different geometries, $\Delta E_{\mathrm{nn}}$ is the energy change for nuclear repulsion, $\Delta E_{\mathrm{en}}$ is the change in electronic-nuclear attraction energy, $\Delta E_{\mathrm{ee}}$ is the change in electron repulsion, and $\Delta E_{\mathrm{k}}$ is the change in kinetic energy. It can be seen that this equation describes the total energy change as a sum of all potential and kinetic contributions.

Table S5 (Ref. 20) illustrates the fact that the repulsive terms, $E_{\mathrm{ee}}$ and $E_{\mathrm{nn}}$, are smallest in the most stable conformation and that they increase when going to the top of the barrier, while the attractive term $E_{\text {en }}$ favors the anti, gauche $\left(C_{1}\right)$ conformer. More detailed results for the energy as a function of the CSCC torsion are shown in Fig. 4.

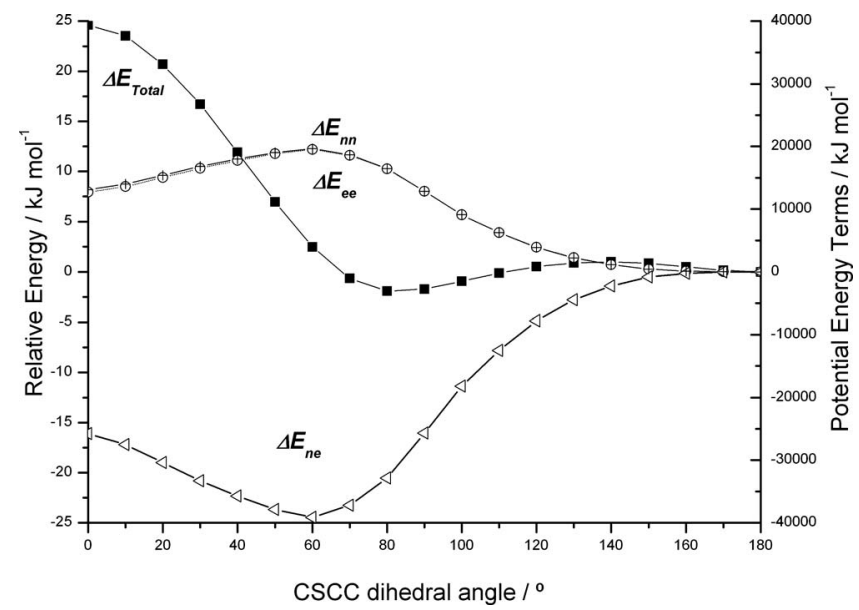

FIG. 4. Dependence of attractive $\left(\Delta E_{\mathrm{ne}}\right)$ and repulsive $\left(\Delta E_{\mathrm{nn}}\right.$ and $\left.\Delta E_{\mathrm{ee}}\right)$ energy increments on the CSCC dihedral angle in $\mathrm{CF}_{3} \mathrm{COSCH}_{2} \mathrm{CH}_{3}$ calculated at the B3LYP/6-311++G(d,p) level.
The relative stabilization of the $C_{s}$ conformer could be interpreted as a repulsive interaction between the lone pairs on sulfur and the electronic charge of the $\mathrm{C}(7 / 21)-\mathrm{C}(10 / 24)$ bond, which is minimized when the symmetry is $C_{s}$. This is commensurate with the fact that the repulsive terms, $E_{\mathrm{ee}}$ and $E_{\mathrm{nn}}$, are smaller in the $C_{s}$ conformer. The lone pairs, named $\operatorname{lp}(1)$ and $\operatorname{lp}(2)$, on the $S$ atom are considerably more stable in the $C_{s}$ conformer than in the $C_{1}$ conformer. The same trend is observed for the $\sigma[\mathrm{C}(7 / 21)-\mathrm{C}(10 / 24)]$ bond orbitals and their antibonding counterparts. The energies and occupancies of the NBOs are listed in Table S6. ${ }^{20}$

\section{GED STUDY}

On the basis of the calculations described above [MP2/6-311++G(d,p)], a two-conformer model was written (conformer 1 with $C_{1}$ symmetry and conformer 2 with $C_{s}$ symmetry), describing both geometries in terms of 36 refinable parameters, comprising eight bond lengths and differences, 24 angles and differences, and four dihedral angles (for conformer 1 only). One extra parameter was included (see Table III) to allow the proportion of each conformer present in the mixture to be altered. The atom numbering used in the descriptions of the parameters is shown in Fig. 1.

All $\mathrm{C}-\mathrm{F}, \mathrm{C}=\mathrm{O}$, and $\mathrm{C}-\mathrm{C}$ distances for both conformers were combined to give an overall average value, and the individual distances (averaged across the two conformers) were described using combinations of differences. The very small differences between the values of these distances in the two conformers were described within the model using parameters that were fixed at calculated values and not allowed to refine. The averages and differences were defined as follows:

$$
\begin{aligned}
p_{1}= & \left\{\left[\mathrm{C}(2 / 16)=\mathrm{O}(6 / 20)_{\text {mean }}\right]\right. \\
& +\left[\mathrm{C}(1 / 15)-\mathrm{F}(4 / 18)_{\text {mean }}\right] \\
& +2\left[\mathrm{C}(1 / 15)-\mathrm{F}(3 / 5 / 17 / 19)_{\text {mean }}\right] \\
& +\left[\mathrm{C}(7 / 21)-\mathrm{C}(10 / 24)_{\text {mean }}\right] \\
& \left.+\left[\mathrm{C}(1 / 15)-\mathrm{C}(2 / 16)_{\text {mean }}\right]\right\} / 6, \\
p_{2}= & {\left[\mathrm{C}(1 / 15)-\mathrm{C}(2 / 16)_{\text {mean }}\right] } \\
& -\left\{\left[\mathrm{C}(2 / 16)=\mathrm{O}(6 / 20)_{\text {mean }}\right]\right. \\
& +\left[\mathrm{C}(1 / 15)-\mathrm{F}(4 / 18)_{\text {mean }}\right] \\
& +2\left[\mathrm{C}(1 / 15)-\mathrm{F}(3 / 5 / 17 / 19)_{\text {mean }}\right] \\
& \left.+\left[\mathrm{C}(7 / 21)-\mathrm{C}(10 / 24)_{\text {mean }}\right]\right\} / 5, \\
p_{3}= & {\left[\mathrm{C}(7 / 21)-\mathrm{C}(10 / 24)_{\text {mean }}\right] } \\
& -\left\{\left[\mathrm{C}(2 / 16)=\mathrm{O}(6 / 20)_{\text {mean }}\right]\right. \\
& +\left[\mathrm{C}(1 / 15)-\mathrm{F}(4 / 18)_{\text {mean }}\right] \\
& \left.+2\left[\mathrm{C}(1 / 15)-\mathrm{F}(3 / 5 / 17 / 19)_{\text {mean }}\right]\right\} / 4,
\end{aligned}
$$


TABLE III. Refined $\left(r_{\mathrm{h} 1}\right)$ and calculated [refers to MP2/6-311++G(d,p) calculations] $\left(r_{\mathrm{e}}\right)$ geometrical parameters for $\mathrm{CF}_{3} \mathrm{COSCH}_{2} \mathrm{CH}_{3}$ from the GED study. [Distances $(r)$ are in pm, and angles $(\angle)$ are in degrees. See text for parameter definitions and Fig. 1 for atom numbering. The figures in parentheses are the estimated standard deviations of the last digits. Conformer 1 has $C_{1}$ symmetry, and conformer 2 has $C_{s}$ symmetry.]

\begin{tabular}{|c|c|c|c|c|}
\hline & Parameter & $r_{\mathrm{h} 1}$ & $r_{\mathrm{e}}$ & Restraint \\
\hline \multicolumn{5}{|c|}{ Independent } \\
\hline$p_{1}$ & $r \mathrm{CF} / \mathrm{CO} / \mathrm{CC}$ average & $138.58(12)$ & 138.29 & $\cdots$ \\
\hline$p_{2}$ & $r \mathrm{CF} / \mathrm{CO} / \mathrm{CC}$ difference 1 & 19.24(35) & 19.57 & $19.57(50)$ \\
\hline$p_{3}$ & $r \mathrm{CF} / \mathrm{CO} / \mathrm{CC}$ difference 2 & $22.29(43)$ & 21.90 & $21.90(50)$ \\
\hline$p_{4}$ & $r \mathrm{CF} / \mathrm{CO} / \mathrm{CC}$ difference 3 & $6.21(39)$ & 5.90 & $5.90(50)$ \\
\hline$p_{5}$ & $r \mathrm{CF} / \mathrm{CO} / \mathrm{CC}$ difference 4 & $12.52(41)$ & 12.60 & $12.60(50)$ \\
\hline$p_{6}$ & $r \mathrm{CS}$ average & $179.30(14)$ & 178.33 & $\cdots$ \\
\hline$p_{7}$ & $r \mathrm{CS}$ difference & $-6.69(50)$ & -6.45 & $-6.45(50)$ \\
\hline$p_{8}$ & $r \mathrm{CH}$ mean & 109.6(6) & 109.2 & $109.2(7)$ \\
\hline$p_{9}$ & $\angle \mathrm{CCH}$ average & $112.6(10)$ & 110.6 & $110.6(10)$ \\
\hline$p_{10}$ & $\angle \mathrm{CCH}$ difference 1 & $-0.3(5)$ & -0.3 & $-0.3(5)$ \\
\hline$p_{11}$ & $\angle \mathrm{CCH}$ difference 2 & $-1.0(5)$ & -1.1 & $-1.1(5)$ \\
\hline$p_{12}$ & $\angle \mathrm{CCH}$ difference 3 & $0.2(5)$ & 0.2 & $0.2(5)$ \\
\hline$p_{13}$ & $\angle \mathrm{CCH}$ difference 4 & $-1.9(5)$ & -2.1 & $-2.1(5)$ \\
\hline$p_{14}$ & $\angle \mathrm{H}(11) \mathrm{C}(10) \mathrm{H}(13)$ & 108.2(9) & 108.2 & $108.2(8)$ \\
\hline$p_{15}$ & $\angle \mathrm{H}(11) \mathrm{C}(10) \mathrm{H}(12)$ & $108.5(9)$ & 108.4 & $108.4(8)$ \\
\hline$p_{16}$ & $\angle \mathrm{H}(25) \mathrm{C}(24) \mathrm{H}(26 / 27)$ & $108.2(9)$ & 108.1 & $108.1(8)$ \\
\hline$p_{17}$ & $\angle \mathrm{CSC}$ mean & $95.9(6)$ & 97.5 & $97.5(10)$ \\
\hline$p_{18}$ & $\angle \mathrm{SCC}\left(\mathrm{F}_{3}\right)$ average & $114.0(3)$ & 114.9 & $114.9(10)$ \\
\hline$p_{19}$ & $\angle \mathrm{SCC}\left(\mathrm{F}_{3}\right)$ difference & $-0.5(5)$ & -0.6 & $-0.6(5)$ \\
\hline$p_{20}$ & $\angle \mathrm{CCF}$ average & 111.4(1) & 110.6 & $\cdots$ \\
\hline$p_{21}$ & $\angle \mathrm{CCF}$ difference 1 & $0.3(5)$ & 0.0 & $0.0(5)$ \\
\hline$p_{22}$ & $\angle \mathrm{CCF}$ difference 2 & $2.3(5)$ & 2.7 & $2.7(5)$ \\
\hline$p_{23}$ & $\angle \mathrm{CCF}$ difference 3 & $1.5(5)$ & 1.4 & $1.4(5)$ \\
\hline$p_{24}$ & $\angle \mathrm{CCF}$ difference 4 & $2.8(5)$ & 2.8 & $2.8(5)$ \\
\hline$p_{25}$ & $\angle \mathrm{F}(3) \mathrm{C}(1) \mathrm{F}(4)$ & $109.0(9)$ & 108.4 & $108.4(10)$ \\
\hline$p_{26}$ & $\angle \mathrm{F}(5) \mathrm{C}(1) \mathrm{F}(4)$ & $108.3(9)$ & 108.1 & 108.1(10) \\
\hline$p_{27}$ & $\angle \mathrm{F}(17 / 19) \mathrm{C}(15) \mathrm{F}(18)$ & $108.2(9)$ & 108.2 & $108.2(10)$ \\
\hline$p_{28}$ & $\angle \mathrm{CC}=\mathrm{O}$ mean & $119.5(6)$ & 119.1 & 119.1(10) \\
\hline$p_{29}$ & $\angle \mathrm{H}(8) \mathrm{C}(7) \mathrm{H}(9)$ & $108.2(7)$ & 108.3 & $108.3(7)$ \\
\hline$p_{30}$ & $\angle \mathrm{H}(22) \mathrm{C}(21) \mathrm{H}(23)$ & $108.3(7)$ & 108.3 & $108.3(7)$ \\
\hline$p_{31}$ & $\angle \mathrm{SCC}\left(\mathrm{H}_{3}\right)$ average & $113.1(6)$ & 111.1 & $\cdots$ \\
\hline$p_{32}$ & $\angle \mathrm{SCC}\left(\mathrm{H}_{3}\right)$ difference & $3.8(6)$ & 3.5 & $3.5(6)$ \\
\hline$p_{33}$ & $\phi \mathrm{F}(4) \mathrm{C}(1) \mathrm{C}(2) \mathrm{S}(14)$ & $4.1(41)$ & 16.9 & $\cdots$ \\
\hline$p_{34}$ & $\phi \mathrm{C}(1) \mathrm{C}(2) \mathrm{S}(14) \mathrm{C}(7)$ & $161.4(27)$ & 173.8 & $\cdots$ \\
\hline$p_{35}$ & $\phi \mathrm{C}(2) \mathrm{S}(14) \mathrm{C}(7) \mathrm{C}(10)$ & $-78.0(22)$ & -78.4 & $-78.4(30)$ \\
\hline$p_{36}$ & $\phi \mathrm{H}(11) \mathrm{C}(10) \mathrm{C}(7) \mathrm{S}(14)$ & $-176.5(51)$ & -178.1 & $-178.1(50)$ \\
\hline$p_{37}$ & Amount of $C_{1}$ conformer & $0.49(3)$ & 0.41 & $\cdots$ \\
\hline \multicolumn{5}{|c|}{ Dependent } \\
\hline$p_{38}$ & $r \mathrm{C}(2)=\mathrm{O}(6)$ & $121.6(3)$ & 121.4 & $\cdots$ \\
\hline$p_{39}$ & $r \mathrm{C}(16)=\mathrm{O}(20)$ & $121.6(3)$ & 121.4 & $\cdots$ \\
\hline$p_{40}$ & $r \mathrm{C}(1)-\mathrm{F}(4)$ & $134.1(4)$ & 134.0 & $\cdots$ \\
\hline$p_{41}$ & $r \mathrm{C}(15)-\mathrm{F}(18)$ & $134.1(4)$ & 134.0 & $\cdots$ \\
\hline$p_{42}$ & $r \mathrm{C}(1)-\mathrm{F}(3)$ & $133.6(2)$ & 133.2 & $\cdots$ \\
\hline$p_{43}$ & $r \mathrm{C}(1)-\mathrm{F}(5)$ & $134.4(2)$ & 134.0 & $\cdots$ \\
\hline$p_{44}$ & $r \mathrm{C}(15)-\mathrm{F}(17 / 19)$ & $134.0(2)$ & 133.6 & $\cdots$ \\
\hline$p_{45}$ & $r \mathrm{C}(7)-\mathrm{S}(14)$ & $182.6(3)$ & 181.5 & $\cdots$ \\
\hline$p_{46}$ & $r \mathrm{C}(21)-\mathrm{S}(28)$ & $182.7(3)$ & 181.6 & $\cdots$ \\
\hline$p_{47}$ & $r \mathrm{C}(7)-\mathrm{C}(10)$ & $153.2(5)$ & 152.5 & $\cdots$ \\
\hline$p_{48}$ & $r \mathrm{C}(21)-\mathrm{C}(24)$ & $153.3(5)$ & 152.6 & $\cdots$ \\
\hline$p_{49}$ & $r \mathrm{C}(1)-\mathrm{C}(2)$ & $154.6(3)$ & 154.6 & $\cdots$ \\
\hline$p_{50}$ & $r \mathrm{C}(15)-\mathrm{C}(16)$ & $154.6(3)$ & 154.6 & $\cdots$ \\
\hline$p_{51}$ & $r \mathrm{C}(2)-\mathrm{S}(14)$ & 176.1(3) & 175.2 & $\cdots$ \\
\hline$p_{52}$ & $r \mathrm{C}(16)-\mathrm{S}(28)$ & $175.9(3)$ & 175.0 & $\cdots$ \\
\hline$p_{53}$ & $\angle \mathrm{CCH}(11)$ & $111.8(11)$ & 109.7 & $\cdots$ \\
\hline$p_{54}$ & $\angle \mathrm{CCH}(12)$ & $112.9(11)$ & 110.9 & $\cdots$ \\
\hline
\end{tabular}

TABLE III. (Continued.)

\begin{tabular}{llcrc}
\hline \hline & Parameter & $r_{\mathrm{h} 1}$ & $r_{\mathrm{e}}$ & Restraint \\
\hline$p_{55}$ & $\angle \mathrm{CCH}(13)$ & $112.7(11)$ & 110.7 & $\ldots$ \\
$p_{56}$ & $\angle \mathrm{CCH}(25)$ & $111.5(11)$ & 109.3 & $\ldots$ \\
$p_{57}$ & $\angle \mathrm{CCH}(26 / 27)$ & $113.5(11)$ & 111.4 & $\ldots$ \\
$p_{58}$ & $\angle \mathrm{C}(2) \mathrm{S}(14) \mathrm{C}(7)$ & $95.9(6)$ & 97.6 & $\ldots$ \\
$p_{59}$ & $\angle \mathrm{C}(16) \mathrm{S}(28) \mathrm{C}(21)$ & $95.9(6)$ & 97.4 & $\ldots$ \\
$p_{60}$ & $\angle \mathrm{CCF}(4)$ & $113.1(4)$ & 112.4 & $\ldots$ \\
$p_{61}$ & $\angle \mathrm{CCF}(3)$ & $111.5(4)$ & 110.4 & $\ldots$ \\
$p_{62}$ & $\angle \mathrm{CCF}(5)$ & $110.0(4)$ & 109.0 & $\ldots$ \\
$p_{63}$ & $\angle \mathrm{CCF}(18)$ & $113.1(4)$ & 112.5 & $\ldots$ \\
$p_{64}$ & $\angle \mathrm{CCF}(17 / 19)$ & $110.3(4)$ & 109.7 & $\ldots$ \\
$p_{65}$ & $\angle \mathrm{S}(14) \mathrm{C}(7) \mathrm{C}(10)$ & $115.0(6)$ & 112.8 & $\ldots$ \\
$p_{66}$ & $\angle \mathrm{S}(28) \mathrm{C}(21) \mathrm{C}(24)$ & $111.3(7)$ & 109.3 & $\ldots$ \\
$p_{67}$ & $\angle \mathrm{S}(14) \mathrm{C}(2) \mathrm{C}(1)$ & $113.7(4)$ & 114.6 & $\ldots$ \\
$p_{68}$ & $\angle \mathrm{S}(28) \mathrm{C}(16) \mathrm{C}(15)$ & $114.3(4)$ & 115.2 & $\ldots$ \\
\hline \hline
\end{tabular}

$$
\begin{aligned}
p_{4}= & {\left[\mathrm{C}(1 / 15)-\mathrm{F}(3 / 5 / 17 / 19)_{\text {mean }}\right] } \\
& -\left\{\left[\mathrm{C}(2 / 16)=\mathrm{O}(6 / 20)_{\text {mean }}\right]\right. \\
& \left.+\left[\mathrm{C}(1 / 15)-\mathrm{F}(4 / 18)_{\text {mean }}\right]\right\} / 2, \\
p_{5}= & {\left[\mathrm{C}(1 / 15)-\mathrm{F}(4 / 18)_{\text {mean }}\right] } \\
& -\left[\mathrm{C}(2 / 16)=\mathrm{O}(6 / 20)_{\text {mean }}\right],
\end{aligned}
$$

and the distances were constructed thus

$$
\begin{aligned}
& {\left[\mathrm{C}(2 / 16)=\mathrm{O}(6 / 20)_{\text {mean }}\right]=} p_{1}-p_{2} / 6-p_{3} / 5-p_{4} / 2 \\
&-p_{5} / 5, \\
& {\left[\mathrm{C}(2 / 16)-\mathrm{O}(14 / 28)_{\text {mean }}\right] }=p_{1}-p_{2} / 6-p_{3} / 5-p_{4} / 2 \\
&+p_{5} / 2, \\
& {\left[\mathrm{C}(1 / 15)-\mathrm{F}(3 / 17)_{\text {mean }}\right]=} p_{1}-p_{2} / 6-p_{3} / 5+p_{4} / 2, \\
& {\left[\mathrm{C}(1 / 15)-\mathrm{F}(4 / 5 / 18 / 19)_{\text {mean }}\right]=p_{1}-p_{2} / 6+4 \times p_{3} / 5, } \\
& {\left[\mathrm{C}(7 / 21)-\mathrm{O}(14 / 28)_{\text {mean }}\right]=} p_{1}+5 \times p_{2} / 6 .
\end{aligned}
$$

The mean $\mathrm{C}-\mathrm{S}$ distances were described by the average of $\left[\mathrm{C}(2 / 16)-\mathrm{S}(14-28)_{\text {mean }}\right]$ and $\left[\mathrm{C}(7 / 21)-\mathrm{S}(14 / 28)_{\text {mean }}\right]$ and the difference between them $\left(p_{6-7}\right)$. A single mean $\mathrm{C}-\mathrm{H}$ parameter $\left(p_{8}\right)$ completed the set of distance parameters used in the model.

Between the two conformers there are five unique $\mathrm{C}-\mathrm{C}-\mathrm{H}$ angles, and these were described as the overall average and a series of four differences,

$$
\begin{aligned}
p_{9}= & \mathrm{CCH}(11) / 6+\mathrm{CCH}(12) / 6+\mathrm{CCH}(13) / 6 \\
& +\mathrm{CCH}(25) / 6+2 \times \mathrm{CCH}(26 / 27) / 6, \\
p_{10}= & {[\mathrm{CCH}(11) / 3+\mathrm{CCH}(12) / 3+\mathrm{CCH}(13) / 3] } \\
& -[\mathrm{CCH}(25) / 3+2 \times \mathrm{CCH}(26 / 27) / 3], \\
p_{11}= & \mathrm{CCH}(11) / 3-[\mathrm{CCH}(12) / 2+\mathrm{CCH}(13) / 2], \\
p_{12}= & \mathrm{CCH}(12)-\mathrm{CCH}(13),
\end{aligned}
$$




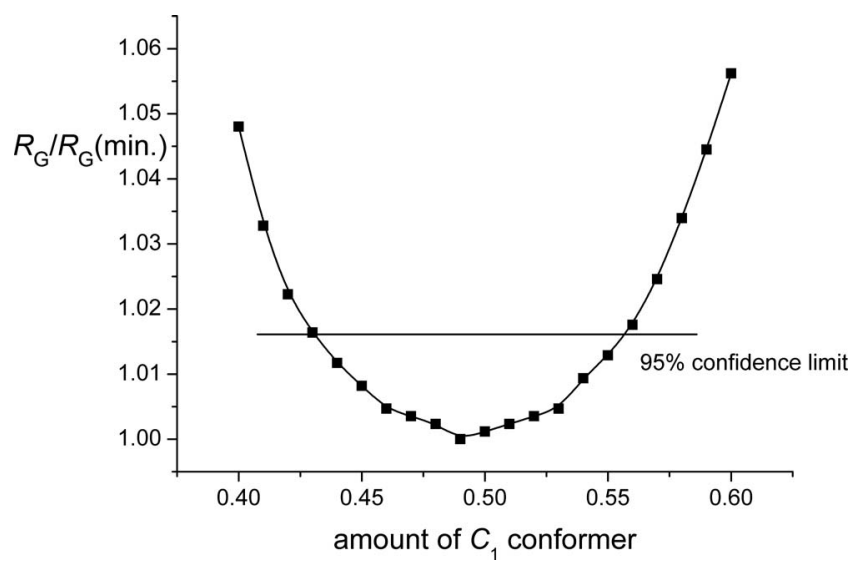

FIG. 5. Proportion of the $C_{1}$-symmetric conformer in experimental mixture against $R_{\mathrm{G}} / R_{\mathrm{G}}(\mathrm{min})$. The horizontal line gives an estimate of the uncertainty $(2 \sigma)$ of the value.

$$
p_{13}=\mathrm{CCH}(25)-\mathrm{CCH}(26 / 27) \text {, }
$$

with the individual angles therefore defined as

$$
\begin{aligned}
& \mathrm{CCH}(11)=p_{9}+p_{10} / 2+2 \times p_{11} / 3, \\
& \mathrm{CCH}(12)=p_{9}+p_{10} / 2-p_{11} / 3+p_{12} / 2, \\
& \mathrm{CCH}(13)=p_{9}+p_{10} / 2-p_{11} / 3-p_{12} / 2, \\
& \mathrm{CCH}(25)=p_{9}-p_{10} / 2+2 \times p_{13} / 3, \\
& \mathrm{CCH}(26 / 27)=p_{9}-p_{10} / 2-p_{13} / 3 .
\end{aligned}
$$

Three $\mathrm{H}-\mathrm{C}-\mathrm{H}$ angles $\left(p_{14-16}\right)$ relating to the internal angles within the methyl groups were used-two for the $C_{1}$ conformer and one for the $C_{s}$ conformer. As the $\mathrm{C}(2)-\mathrm{S}(14)-\mathrm{C}(7)$ and $\mathrm{C}(16)-\mathrm{S}(28)-\mathrm{C}(21)$ angles were calculated to be almost identical, a single mean value $\left(p_{17}\right)$ was used to describe both. The $\mathrm{S}(14)-\mathrm{C}(2)-\mathrm{C}(1)$ and $S(28)-C(16)-C(15)$ angles were described using the average of the two values and the difference between them $\left(p_{18-19}\right)$. In a manner identical to that used for the $\mathrm{CCH}$ angles, the CCF angles were described using the average of all five and a set of differences $\left(p_{20-24}\right)$. Three FCF angles completed the description of the $\mathrm{CF}_{3}$ groups $\left(p_{25-27}\right)$. A mean $\mathrm{C}-\mathrm{C}=\mathrm{O}$ value was used in the model $\left(p_{28}\right)$, reflecting the similarity of the calculated values for the two conformers. The methylene groups of the two conformers were described using different $\mathrm{H}-\mathrm{C}-\mathrm{H}$ angles $\left(p_{29-30}\right)$. Unsurprisingly, the $\mathrm{S}(14)-\mathrm{C}(7)-\mathrm{C}(10)$ and $\mathrm{S}(28)-\mathrm{C}(21)-\mathrm{C}(24)$ angles were quite different and were therefore described using the average of the two and their difference $\left(p_{31-32}\right)$. Finally, the model was completed using four dihedral angles $\left(p_{33-37}\right)$ to describe the deviation of the $C_{1}$ conformer from $C_{s}$ symmetry. All 36 independent geometric parameters were refined by least-squares. Restraints were applied, using the SARACEN method, ${ }^{43}$ to parameters that could otherwise not be refined (Table III). The restraints were based on values calculated at the MP2/6-311++G(d,p) level, and the uncertainties were derived from the changes in value of each parameter during the series of calculations that was performed. In addition, ten groups of amplitudes of vibration were refined. (See Table S7 for a list of amplitudes of vibration). ${ }^{20}$ Finally, the relative amounts of each conformer in the experimental mixture were estimated by changing parameter 37 in a stepwise manner and recording the $R$ factor. Figure 5 shows these $R$ factors plotted in the form $R_{\mathrm{G}} / R_{\mathrm{G}}(\mathrm{min})$ against the amount of $C_{1}$ conformer, showing that the best fit to the experimental data occurs with a ratio of $C_{1}$ to $C_{s}$ conformer of approximately 49:51. Using Hamilton's statistical tables, ${ }^{44}$ the standard deviation of the amount of each conformer has been estimated by drawing a horizontal line at $R_{\mathrm{G}} / R_{\mathrm{G}}(\min )=1.016$, representing the $95 \%$ confidence limit $(2 \sigma)$. This leads to the amount of $C_{1}$ conformer, including estimated standard deviation, of 49(3)\% and a corresponding difference in energy of $1.79 \mathrm{~kJ} \mathrm{~mol}^{-1}$, with the $C_{s}$ conformer

\begin{tabular}{|c|c|c|c|c|c|c|}
\hline & $\mathrm{CF}_{3} \mathrm{C}(\mathrm{O}) \mathrm{SH}^{\mathrm{a}}$ & $\mathrm{CF}_{3} \mathrm{C}(\mathrm{O}) \mathrm{SCl}^{\mathrm{a}}$ & $\mathrm{CF}_{3} \mathrm{C}(\mathrm{O}) \mathrm{SCH}_{3}{ }^{\mathrm{a}}$ & $\mathrm{CF}_{3} \mathrm{C}(\mathrm{O}) \mathrm{SCH}_{2} \mathrm{CH}_{3}{ }^{\mathrm{b}}$ & $\mathrm{ClC}(\mathrm{O}) \mathrm{SCH}_{2} \mathrm{CH}_{3}{ }^{\mathrm{c}}$ & $\mathrm{CH}_{3} \mathrm{C}(\mathrm{O}) \mathrm{SCH}_{2} \mathrm{CH}_{3}$ \\
\hline$r \mathrm{C}-\mathrm{S}$ & 173.8 & 176.5 & 174.3 & 175.9 & 175.2 & 178.6 \\
\hline$r \mathrm{~S}-\mathrm{Y}$ & 133.5 & 201.3 & 180.7 & 182.7 & 180.0 & 184.5 \\
\hline$r \mathrm{C}=\mathrm{O}$ & 121.7 & 122.4 & 120.6 & 121.6 & 120.0 & 121.5 \\
\hline$r \mathrm{R}-\mathrm{C}(\mathrm{O})$ & 152.4 & 154.6 & 152.7 & 154.6 & 172.5 & 151.3 \\
\hline$\angle \mathrm{S}-\mathrm{C}=\mathrm{O}$ & 127.6 & 126.4 & 126.1 & 125.8 & $127.6^{\mathrm{d}}$ & 118.2 \\
\hline$\angle \mathrm{C}-\mathrm{S}-\mathrm{Y}$ & 96.5 & 99.4 & 98.1 & 95.9 & 103.9 & 104.7 \\
\hline $\mathrm{n}(\sigma) \mathrm{S} \rightarrow \sigma^{*} \mathrm{C}=\mathrm{O}$ & 20.61 & 17.43 & 22.36 & 22.91 & 27.4 & $\cdots$ \\
\hline $\mathrm{n}(\pi) \mathrm{S} \rightarrow \pi^{*} \mathrm{C}=\mathrm{O}$ & 132.13 & 123.64 & 151.61 & 153.23 & 151.1 & 120.75 \\
\hline Sum $\mathrm{nS} \rightarrow \pi^{*} \mathrm{C}=\mathrm{O}$ & 152.74 & 142.83 & 174.0 & 176.14 & 178.5 & 120.75 \\
\hline $\mathrm{n}(\sigma) \mathrm{O} \rightarrow \sigma^{*} \mathrm{C}-\mathrm{S}$ & 8.78 & 7.48 & 7.77 & 8.19 & 12.62 & 6.77 \\
\hline $\mathrm{n}(\pi) \mathrm{O} \rightarrow \pi^{*} \mathrm{C}-\mathrm{S}$ & 133.22 & 150.48 & 126.19 & 123.94 & 102.36 & 134.4 \\
\hline Sum $\mathrm{nO} \rightarrow \pi^{*} \mathrm{C}-\mathrm{S}$ & 141.99 & 157.96 & 133.97 & 132.13 & 114.99 & 141.2 \\
\hline Sum total ${ }^{\mathrm{c}}$ & 294.73 & 299.04 & 307.94 & 308.27 & 293.49 & 261.95 \\
\hline
\end{tabular}
lower in energy.

The success of the refinement can be assessed numerically using the final $R$ factor, which was $R_{\mathrm{G}}=0.092\left(R_{\mathrm{D}}\right.$

TABLE IV. Selected GED experimental bond length and hyperconjugation interactions calculated with B3LYP/6-311++G(d,p) to the YSC(O)R moiety. All NBO energies are from B3LYP/6-311++G(d,p) calculations from this work. Distances are in picometer, angles are in degrees, and energies are in $\mathrm{kJ} \mathrm{mol}^{-1}$.

\footnotetext{
${ }^{\mathrm{a}}$ GED parameters from Ref. 46.

${ }^{\mathrm{b}}$ This work.

${ }^{\mathrm{c}}$ Experimental geometrical parameters from Ref. 47.

${ }^{\mathrm{d}}$ Calculated value.
} 
TABLE V. Frequencies $/ \mathrm{cm}^{-1}$ and observed bands in the infrared and Raman spectra of $\mathrm{CF}_{3} \mathrm{COSCH}_{2} \mathrm{CH}_{3}$.

\begin{tabular}{|c|c|c|c|c|}
\hline \multicolumn{3}{|c|}{ Infrared $^{\mathrm{a}}$} & \multirow{2}{*}{$\frac{\text { Raman }^{\mathrm{b}}}{\text { Liquid }}$} & \multirow{2}{*}{$\begin{array}{l}\text { Approximate } \\
\text { description }\end{array}$} \\
\hline Gas & Liquid (RT) & Low temp. $\left(-100^{\circ} \mathrm{C}\right)$ & & \\
\hline \multicolumn{2}{|l|}{$3005 \mathrm{sh}$} & $3005 \mathrm{sh}$ & & $\nu_{\mathrm{a}} \mathrm{CH}_{2}$ \\
\hline $2995 \mathrm{sh}$ & $2995 \mathrm{sh}$ & $2995 \mathrm{sh}$ & & $\nu_{\mathrm{a}} \mathrm{CH}_{3}$ \\
\hline $2989 \mathrm{w}\left(C_{s}\right) 2983 \mathrm{w}\left(C_{1}\right)$ & $2982 \mathrm{w}$ & $2982 \mathrm{~m}$ & $2981(31)\left(C_{s}\right) 2979 \mathrm{sh}\left(C_{1}\right)$ & $\nu_{\mathrm{a}} \mathrm{CH}_{3}$ \\
\hline 29502947 w 2945 & $2947 \mathrm{sh}\left(C_{s}\right) 2942 \mathrm{w}\left(C_{1}\right)$ & $2941 \mathrm{~m}$ & $2942(100)$ & $\nu_{\mathrm{s}} \mathrm{CH}_{2}$ \\
\hline $2891 \mathrm{w}\left(C_{s}\right) 2889 \mathrm{w}\left(C_{1}\right)$ & $2886 \mathrm{vw} 2884 \mathrm{vw}$ & $2885 \mathrm{~m}$ & $2886(24)$ & $\nu_{\mathrm{s}} \mathrm{CH}_{3}$ \\
\hline 1724 vs & $1709 \mathrm{v}\left(C_{s}\right) 1700 \mathrm{sh}\left(C_{1}\right)$ & 1705 vs $\left(C_{s}\right) 1692$ vs $\left(C_{1}\right)$ & $1708(24)\left(C_{s}\right) 1696 \mathrm{sh}\left(C_{1}\right)$ & $\nu \mathrm{C}=\mathrm{O}$ \\
\hline \multicolumn{2}{|l|}{$1461 \mathrm{w}$} & $\cdots$ & $1464 \mathrm{sh}$ & $\delta_{\mathrm{a}} \mathrm{CH}_{3}$ \\
\hline \multicolumn{2}{|l|}{$1457 \mathrm{w}$} & $1457 \mathrm{~s}$ & $1457(10)\left(C_{s}\right) 1454(10)\left(C_{1}\right)$ & $\delta_{\mathrm{a}} \mathrm{CH}_{3}$ \\
\hline \multirow{3}{*}{$\begin{array}{l}1457 \mathrm{w} \\
1389 \mathrm{vw} \\
1339 \mathrm{vvw}\left(C_{1}\right) 1337 \mathrm{vvw}\left(C_{s}\right)\end{array}$} & $1420 \mathrm{vw}$ & $1418 \mathrm{~m}$ & $1427 \operatorname{sh}\left(C_{s}\right) 1420(8)\left(C_{1}\right)$ & $\delta \mathrm{CH}_{2}$ \\
\hline & $1387 \mathrm{vw}\left(C_{s}\right) 1383 \mathrm{vw}\left(C_{1}\right)$ & $1391 \mathrm{sh}\left(C_{s}\right) 1382 \mathrm{~m}\left(C_{1}\right)$ & $1390(2)\left(C_{s}\right) 1384(2)\left(C_{1}\right)$ & $\delta_{\mathrm{s}} \mathrm{CH}_{3}$ \\
\hline & $1338 \mathrm{vvw}$ & 1339 w & & $\omega \mathrm{CH}_{2}$ \\
\hline $1290 \mathrm{~s}$ & $1287 \mathrm{~s}$ & 1287 vs & $1287(9)$ & $\nu_{\mathrm{s}} \mathrm{CF}_{3}$ \\
\hline $1273 \mathrm{sh}$ & $1274 \operatorname{sh}\left(C_{s}\right) 1253 \operatorname{sh}\left(C_{1}\right)$ & 1274 vs $\left(C_{s}\right) 1254 \mathrm{~s}\left(C_{1}\right)$ & $1273(6)\left(C_{s}\right) 1253(3)\left(C_{1}\right)$ & $\tau \omega \mathrm{CH}_{2}$ \\
\hline 1214 vs & $1210 \mathrm{vs}$ & 1205 vs & $1206(3)$ & $\nu_{\mathrm{a}} \mathrm{CF}_{3}$ \\
\hline 1187 vs & 1164 vs & 1158 vs & $1171(2)$ & $\nu_{\mathrm{a}} \mathrm{CF}_{3}$ \\
\hline $1061 \mathrm{sh}\left(C_{s}\right) 1056 \mathrm{vvw}\left(C_{1}\right)$ & $1060 \mathrm{w}\left(C_{s}\right) 1054 \mathrm{sh}\left(C_{1}\right)$ & $1062 \mathrm{~m}$ & $1060(19)$ & $\rho \mathrm{CH}_{3}$ \\
\hline $1051 \mathrm{vw}$ & $1051 \mathrm{vvw}$ & $1051 \mathrm{w}$ & $1052 \mathrm{sh}$ & $\rho \mathrm{CH}_{3}$ \\
\hline $995 \mathrm{w}$ & $998 \mathrm{w}$ & $1000 \mathrm{w}$ & $\cdots$ & $\nu \mathrm{C}(7)-\mathrm{C}(10)$ \\
\hline 957 vs & 956 vs & 955 vs & $\begin{array}{l}975(5)\left(C_{s}\right) \\
955(3)\left(C_{1}\right)\end{array}$ & $\nu \mathrm{C}(1)-\mathrm{C}(2)$ \\
\hline 800 & $\cdots$ & $776 \mathrm{w}\left(C_{s}\right) 760 \mathrm{~m}\left(C_{1}\right)$ & $760(9)$ & $\rho \mathrm{CH}_{2}$ \\
\hline $749745 \mathrm{~m} 741$ & $744 \mathrm{~m}$ & $744 \mathrm{~s}$ & $744(30)$ & $\delta_{\mathrm{s}} \mathrm{CF}_{3}$ \\
\hline $703 \mathrm{vw}$ & $695 \mathrm{w}$ & $695 \mathrm{~m}$ & $\cdots$ & $\rho \mathrm{C}=\mathrm{O}$ out-of-plane \\
\hline \multirow{2}{*}{$\begin{array}{l}673 \mathrm{vvw}\left(C_{s}\right) 664 \mathrm{vvw}\left(C_{1}\right) \\
597 \mathrm{w}\left(C_{1}\right) 591 \mathrm{w}\left(C_{s}\right)\end{array}$} & $668 \mathrm{vw}$ & $683 \mathrm{w}\left(C_{s}\right) 664 \mathrm{w}\left(C_{1}\right)$ & $685(10)\left(C_{s}\right) 664(35)\left(C_{1}\right)$ & $\nu \mathrm{C}(2)=\mathrm{S}(14)$ \\
\hline & $595 \mathrm{~m}$ & $595 \mathrm{~s}$ & $596(14)$ & $\nu \mathrm{S}-\mathrm{C}(7)$ \\
\hline $533 \mathrm{w}$ & $546 \mathrm{sh}\left(C_{s}\right) 538 \mathrm{vvw}\left(C_{1}\right)$ & $547 \mathrm{sh}\left(C_{s}\right) 539 \mathrm{~m}\left(C_{1}\right)$ & $538(14)$ & $\delta_{\mathrm{a}} \mathrm{CF}_{3}$ \\
\hline \multirow[t]{9}{*}{$511 \mathrm{vw}$} & $510 \mathrm{vvw}$ & $511 \mathrm{~m}$ & $\cdots$ & $\delta_{\mathrm{a}} \mathrm{CF}_{3}$ \\
\hline & & & $404(13)$ & $\rho \mathrm{C}=\mathrm{O}$ in-plane \\
\hline & & & $371 \mathrm{sh}\left(C_{1}\right) 360(9)\left(C_{s}\right)$ & $\delta \mathrm{C}(2) \mathrm{S}(14) \mathrm{C}(7)$ \\
\hline & & & $313(13)\left(C_{1}\right) 295(13)\left(C_{s}\right)$ & $\delta \mathrm{S}(14) \mathrm{C}(7) \mathrm{C}(10)$ \\
\hline & & & $262(3)\left(C_{1}\right) 250(4)\left(C_{s}\right)$ & $\rho \mathrm{CF}_{3}$ \\
\hline & & & $220(14)$ & $\rho \mathrm{CF}_{3}$ \\
\hline & & & $210 \mathrm{sh}$ & $\tau \mathrm{CH}_{3}$ \\
\hline & & & $125(2)$ & $\delta \mathrm{C}(1) \mathrm{C}(2) \mathrm{S}(14)$ \\
\hline & & & $98(16)$ & $\tau \mathrm{S}(14) \mathrm{C}(10)$ \\
\hline
\end{tabular}

sh: shoulder; s: strong; w: weak; m: medium; and v: very.

${ }^{\mathrm{b}}$ Relative band heights in parentheses.

$=0.053)$, and visually using the goodness of fit of the radialdistribution and difference curves, as seen in Fig. 6, and the molecular-scattering intensity curves (Fig. S3). ${ }^{20}$ The leastsquares correlation matrix is given in Table S8 (Ref. 20), and coordinates for the final GED structures and for the calculated structures $[\mathrm{MP} 2 / 6-311++\mathrm{G}(\mathrm{d}, \mathrm{p})]$ are given in Tables S9 and S10, respectively. ${ }^{20}$

To allow comparison of the experimental geometrical parameters and conformation of $\mathrm{CF}_{3} \mathrm{CO}_{2} \mathrm{CH}_{2} \mathrm{CH}_{3}$ (Ref. 5) with those for $\mathrm{CF}_{3} \mathrm{COSCH}_{2} \mathrm{CH}_{3}$, we present selected parameters in Table I. In addition, NBO analysis was performed to quantify and compare the role of electron delocalization and the geometrical parameters in each compound.

Replacing the single-bonded oxygen atom in the acetate by sulfur leads to an increase in the $\mathrm{C}(16)-\mathrm{O}(20)$ and $\mathrm{C}(21)-\mathrm{C}(24)$ bond lengths, which can be explained by a decrease of $77 \mathrm{~kJ} \mathrm{~mol}^{-1}$ of the lp S/O(14/28) $\rightarrow \sigma^{*} \mathrm{C}(2 / 16)-\mathrm{O}(6 / 20)$ interactions and by $3.38 \mathrm{~kJ} \mathrm{~mol}^{-1}$ of the $1 \mathrm{p} \mathrm{S} / \mathrm{O}(14 / 28) \rightarrow \sigma^{*} \mathrm{C}(7 / 21)-\mathrm{C}(10 / 24)$ interactions in the thioacetate. There is a slight increase in the $\mathrm{C}(15)-\mathrm{C}(16)-\mathrm{S} / \mathrm{O}(28)$ angle, but the $\mathrm{C}(16)-\mathrm{S} / \mathrm{O}(28)-\mathrm{C}(21)$ angle is of course much narrower in the thioacetate, having sulfur instead of oxygen as the central atom. The $\mathrm{C}(16)-\mathrm{S} / \mathrm{O}(28)-\mathrm{C}(21)-\mathrm{C}(24)$ dihedral angle is much smaller in the gauche conformer of the thioacetate than in the corresponding conformer of the acetate.

The differences in the molecular structure of thioesters and oxoesters and their relation with the hyperconjugative interaction have been confirmed by Erben et al., ${ }^{45}$ who observed that the hyperconjugative interaction is "less important when the donor lone pair is formally located at the sulfur atom rather than at the oxygen atom" It is interesting to compare the effects of the substitution of both trifluoro and ethyl groups on the $\mathrm{R}-\mathrm{C}(\mathrm{O}) \mathrm{S}-\mathrm{Y}$ moiety. In Table IV we present selected parameters and hyperconjugative interactions for $\mathrm{CF}_{3} \mathrm{C}(\mathrm{O}) \mathrm{SH}^{46}{ }^{4} \mathrm{CF}_{3} \mathrm{C}(\mathrm{O}) \mathrm{SCl}^{46} \mathrm{CF}_{3} \mathrm{C}(\mathrm{O}) \mathrm{SCH}_{3}$, $\mathrm{CF}_{3} \mathrm{C}(\mathrm{O}) \mathrm{SCH}_{2} \mathrm{CH}_{3}$, $\mathrm{ClC}(\mathrm{O}) \mathrm{SCH}_{2} \mathrm{CH}_{3},{ }^{47}$ and 


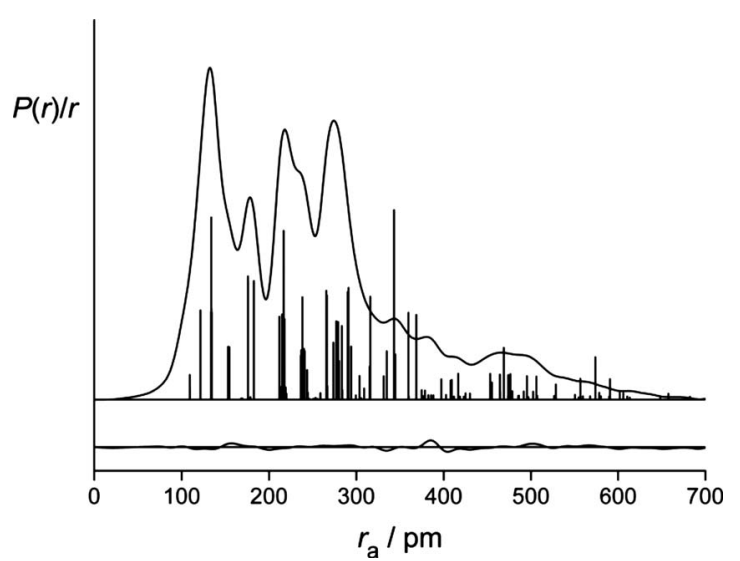

FIG. 6. Experimental radial-distribution curve and theoretical-minusexperimental difference curve for the refinement of $\mathrm{CF}_{3} \mathrm{COSCH}_{2} \mathrm{CH}_{3}$. Before Fourier inversion the data were multiplied by $s \exp \left(-0.00002 s^{2}\right) /\left(Z_{\mathrm{O}}\right.$ $\left.-f_{\mathrm{O}}\right)\left(Z_{\mathrm{F}}-f_{\mathrm{F}}\right)$.

$\mathrm{CH}_{3} \mathrm{C}(\mathrm{O}) \mathrm{SCH}_{2} \mathrm{CH}_{3}$. We are studying the last molecule at the moment and the data used here are results of the theoretical calculations and from the paper of Nagy et al. ${ }^{48,49}$

When we analyze the replacement of the trifluoro group by a less electronegative group such as $\mathrm{CH}_{3}$ or $\mathrm{Cl}$, a decrease in the $\mathrm{C}-\mathrm{S}$ bond length is observed, which can be explained by an increase in the anomeric effect, as seen for $\operatorname{lp} \sigma \mathrm{O} \rightarrow \sigma^{*} \mathrm{C}-\mathrm{S}$ and $\operatorname{lp} \sigma \mathrm{S} \rightarrow \sigma^{*} \mathrm{C}=\mathrm{O}$ in $\mathrm{ClC}(\mathrm{O}) \mathrm{SCH}_{2} \mathrm{CH}_{3} \cdot{ }^{47}$

If we compare the sums of individually determined effects for $\mathrm{Y}=\mathrm{H}, \mathrm{CH}_{3}$, and $\mathrm{CH}_{2} \mathrm{CH}_{3}$ we observe an increase in the delocalization as the chain length increases. The chlorine atom is a special case, as it has a greater electronegativity compared to the other substituents; this results in a decrease in the electronic delocalization in the $\mathrm{R}-\mathrm{C}(\mathrm{O}) \mathrm{S}-\mathrm{Y}$ moiety.

\section{A. Vibrational study}

The details of the IR (gas, liquid, and solid) and Raman spectra, together with a tentative assignment, are collected in

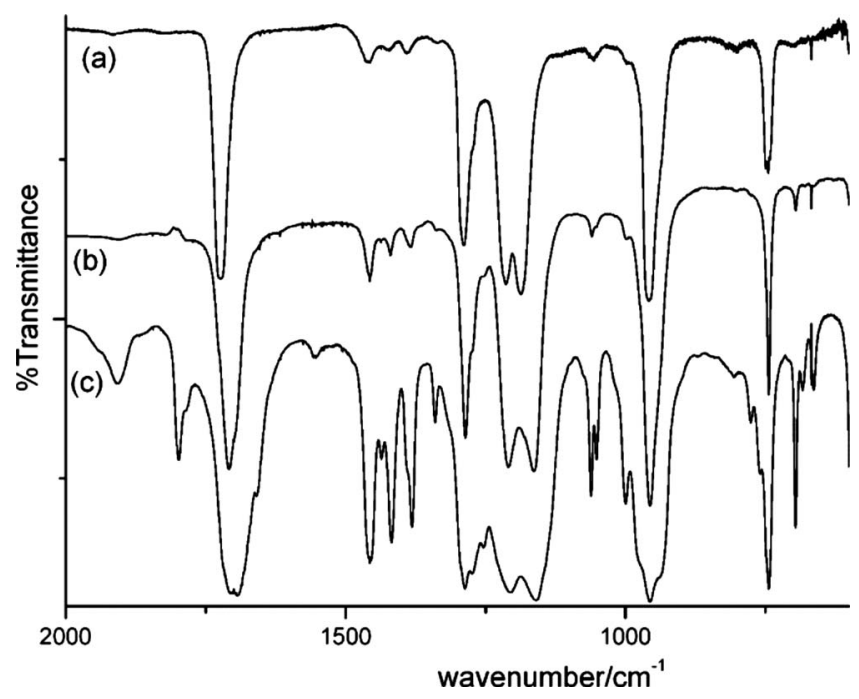

FIG. 7. Infrared spectra in (a) the gas phase (path length of $10 \mathrm{~cm}, 5$ torr), (b) the liquid phase (room temperature), and (c) the solid phase of $\mathrm{CF}_{3} \mathrm{COSCH}_{2} \mathrm{CH}_{3}$ (resolution: $1 \mathrm{~cm}^{-1}$ ).

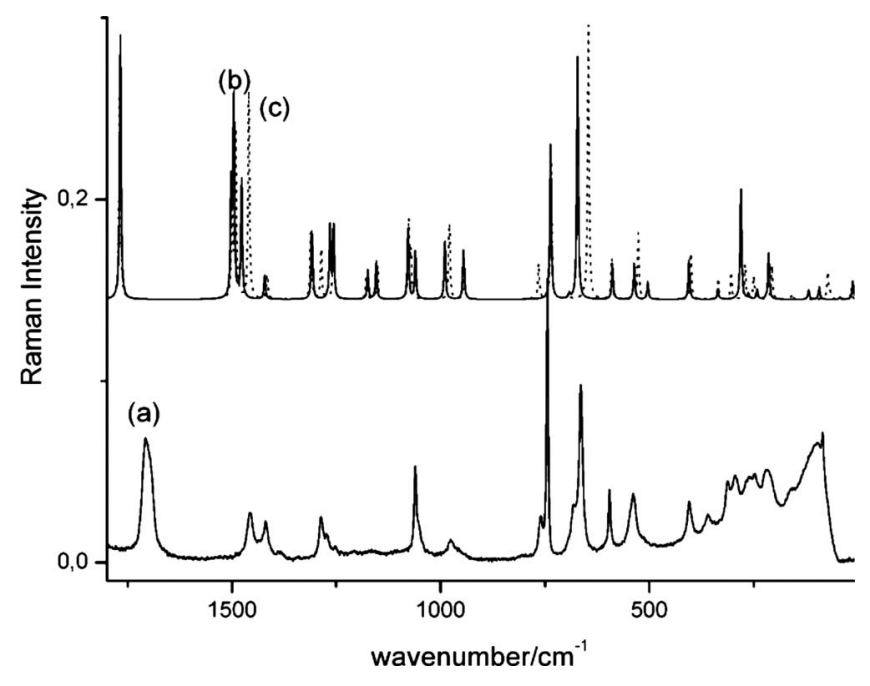

FIG. 8. Infrared and Raman spectra of liquid $\mathrm{CF}_{3} \mathrm{COSCH}_{2} \mathrm{CH}_{3}$ at room temperature.

Table V. Representative spectra are illustrated in Fig. 7 (IR spectra of the gas, liquid, and solid) and Fig. 8 (calculated and experimental Raman spectra).

The calculated wavenumbers for the 36 normal modes of vibration of $\mathrm{CF}_{3} \mathrm{COSCH}_{2} \mathrm{CH}_{3}\left(22 \mathrm{~A}^{\prime}\right.$ and $\left.14 \mathrm{~A}^{\prime \prime}\right)$ for the $C_{s}$ conformer appear in Table VI, where they are compared with the measured values. The assignment of the experimental bands was made after comparison with related molecules and with the results of the calculations.

DFT calculations reproduced the normal wavenumbers of vibrations with the following RMSDs for each basis set: $65 \mathrm{~cm}^{-1}$ for $6-31 \mathrm{G}(\mathrm{d}), 56 \mathrm{~cm}^{-1}$ for $6-311 \mathrm{G}(\mathrm{d}, \mathrm{p})$, and $53 \mathrm{~cm}^{-1}$ for $6-311++\mathrm{G}(\mathrm{d}, \mathrm{p})$. The results with the combination B3LYP/6-311++G(d,p) were used for the vibrational analysis to facilitate the comparison of the present results with those obtained previously for related molecules. At room temperature, most bands are attributable to the same fundamental for both conformations. The IR (gas, liquid, and solid) and Raman spectra demonstrate the presence of conformers of $C_{s}$ and $C_{1}$ symmetry by the resolution of several fundamental modes of vibration.

The bands at 2942 and at $2886 \mathrm{~cm}^{-1}$ in the Raman spectrum are assigned to the symmetric modes of the methylene and methyl groups, respectively. These bands are split into two components in the liquid and gas IR spectra, showing the presence of the two conformers (see Table V).

The carbonyl band is extremely sensitive to the conformers present in the liquid and solid phases. In the gas phase we observed only one band at $1724 \mathrm{~cm}^{-1}$. The pair of strong bands at 1709-1702 and 1700-1692 $\mathrm{cm}^{-1}$ in the liquid and solid infrared spectra is assigned to the $\mathrm{CO}$ stretching mode for $C_{s}$ and $C_{1}$ conformers, respectively (see Table V). The calculated values for both conformers are $1769 \mathrm{~cm}^{-1}\left(C_{1}\right)$ and $1768 \mathrm{~cm}^{-1}\left(C_{s}\right)$.

\section{B. Calculation of force constants}

The force field in Cartesian coordinates, as generated by the Gaussian program, was transformed to the set of nonredundant natural coordinates defined in Table S11. ${ }^{20}$ Such co- 
TABLE VI. Observed and calculated frequencies $/ \mathrm{cm}^{-1}$, infrared and Raman intensity, and potential-energy distribution for $\mathrm{CF}_{3} \mathrm{COSCH}_{2} \mathrm{CH}_{3}$.

\begin{tabular}{|c|c|c|c|c|c|c|}
\hline Mode & Observed & Calculated $^{\mathrm{a}}$ & Calculated SQM ${ }^{\mathrm{b}}$ & IR intensity ${ }^{c}$ & Raman activity $^{\mathrm{d}}$ & Potential-energy distribution \\
\hline \multicolumn{7}{|l|}{$\mathrm{A}^{\prime}$} \\
\hline 1 & 2995 & 3101 & 2985 & 16.74 & 108.20 & $97 \mathrm{~S}_{1}$ \\
\hline 2 & 2947 & 3075 & 2983 & 2.77 & 81.72 & $98 \mathrm{~S}_{2}$ \\
\hline 3 & 2891 & 3036 & 2893 & 18.95 & 190.16 & $100 \mathrm{~S}_{3}$ \\
\hline 4 & 1724 & 1768 & 1729 & 298.35 & 14.15 & $100 \mathrm{~S}_{4}$ \\
\hline 5 & 1461 & 1503 & 1479 & 4.80 & 6.03 & $100 \mathrm{~S}_{5}$ \\
\hline 6 & 1457 & 1478 & 1446 & 4.01 & 6.31 & $90 \mathrm{~S}_{6}+9 \mathrm{~S}_{28}$ \\
\hline 7 & 1389 & 1422 & 1373 & 4.77 & 1.29 & $98 \mathrm{~S}_{7}$ \\
\hline 8 & 1339 & 1308 & 1340 & 37.12 & 3.66 & $92 \mathrm{~S}_{8}$ \\
\hline 9 & 1290 & 1256 & 1277 & 105.81 & 3.86 & $40 \mathrm{~S}_{9}+30 \mathrm{~S}_{12}+30 \mathrm{~S}_{14}$ \\
\hline 10 & 1214 & 1174 & 1211 & 240.10 & 1.56 & $93 \mathrm{~S}_{10}+10 \mathrm{~S}_{17}$ \\
\hline 11 & 1061 & 1078 & 1064 & 11.26 & 3.82 & $45 \mathrm{~S}_{11}+34 \mathrm{~S}_{13}$ \\
\hline 12 & 995 & 989 & 977 & 4.46 & 3.22 & $26 \mathrm{~S}_{9}+11 \mathrm{~S}_{12}+11 \mathrm{~S}_{29}+24 \mathrm{~S}_{16}+35 \mathrm{~S}_{18}$ \\
\hline 13 & 957 & 944 & 955 & 306.58 & 2.65 & $28 \mathrm{~S}_{28}+47 \mathrm{~S}_{13}$ \\
\hline 14 & 745 & 736 & 754 & 43.79 & 8.49 & $32 \mathrm{~S}_{9}+38 \mathrm{~S}_{14}$ \\
\hline 15 & 673 & 672 & 659 & 1.51 & 12.91 & $63 \mathrm{~S}_{15}+6 \mathrm{~S}_{28}+8 \mathrm{~S}_{19}+9 \mathrm{~S}_{32}$ \\
\hline 16 & 597 & 588 & 593 & 4.50 & 1.92 & $27 \mathrm{~S}_{15}+16 \mathrm{~S}_{31}+6 \mathrm{~S}_{27}+7 \mathrm{~S}_{12}+8 \mathrm{~S}_{14}$ \\
\hline 17 & 533 & 536 & 540 & 5.63 & 2.00 & $35 \mathrm{~S}_{16}+37 \mathrm{~S}_{17}$ \\
\hline 18 & 404 & 405 & 413 & 0.41 & 2.05 & $11 \mathrm{~S}_{12}+12 \mathrm{~S}_{16}+24 \mathrm{~S}_{17}+15 \mathrm{~S}_{18}+13 \mathrm{~S}_{19}$ \\
\hline 19 & 360 & 335 & 344 & 3.39 & 0.57 & $23 \mathrm{~S}_{18}+38 \mathrm{~S}_{19}+10 \mathrm{~S}_{20}+9 \mathrm{~S}_{32}$ \\
\hline 20 & 295 & 281 & 284 & 1.43 & 5.86 & $11 \mathrm{~S}_{12}+15 \mathrm{~S}_{17}+23 \mathrm{~S}_{19}+31 \mathrm{~S}_{20}$ \\
\hline 21 & 220 & 215 & 221 & 7.68 & 2.52 & $92 \mathrm{~S}_{12}$ \\
\hline 22 & 125 & 118 & 121 & 0.37 & 0.51 & $20 \mathrm{~S}_{18}+30 \mathrm{~S}_{33}+50 \mathrm{~S}_{22}$ \\
\hline \multicolumn{7}{|r|}{ 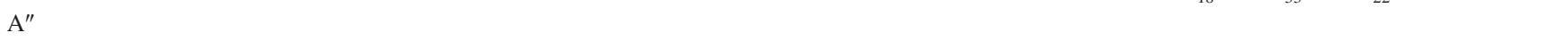 } \\
\hline 23 & 3005 & 3132 & 3009 & 9.86 & 21.22 & $80 \mathrm{~S}_{23}+20 \mathrm{~S}_{24}$ \\
\hline 24 & 2989 & 3101 & 2983 & 9.59 & 77.61 & $20 \mathrm{~S}_{23}+80 \mathrm{~S}_{24}$ \\
\hline 25 & 1457 & 1496 & 1453 & 10.34 & 10.91 & $88 \mathrm{~S}_{25}$ \\
\hline 26 & 1273 & 1265 & 1255 & 0.021 & 3.86 & $63 \mathrm{~S}_{26}+18 \mathrm{~S}_{28}$ \\
\hline 27 & 1187 & 1154 & 1191 & 300.91 & 2.00 & $100 \mathrm{~S}_{27}$ \\
\hline 28 & 1051 & 1060 & 1048 & 0.01 & 2.52 & $34 \mathrm{~S}_{26}+35 \mathrm{~S}_{28}+27 \mathrm{~S}_{13}$ \\
\hline 29 & 776 & 782 & 773 & 3.07 & 0.06 & $40 \mathrm{~S}_{28}+60 \mathrm{~S}_{29}$ \\
\hline 30 & 703 & 692 & 714 & 3.18 & 0.28 & $51 \mathrm{~S}_{30}+20 \mathrm{~S}_{12}$ \\
\hline 31 & 511 & 504 & 521 & 3.95 & 0.91 & $11 \mathrm{~S}_{30}+80 \mathrm{~S}_{31}$ \\
\hline 32 & 250 & 262 & 263 & 2.49 & 0.28 & $26 S_{31}+67 S_{32}$ \\
\hline 33 & 210 & 242 & 216 & 0.63 & 0.52 & $23 \mathrm{~S}_{28}+21 \mathrm{~S}_{33}+33 \mathrm{~S}_{14}$ \\
\hline 34 & 98 & 93 & 83 & 0.72 & 0.68 & $82 \mathrm{~S}_{34}$ \\
\hline 35 & 31 & 43 & 31 & 0.19 & 0.13 & $100 \mathrm{~S}_{35}$ \\
\hline 36 & 10 & 13 & 11 & 0.22 & 0.97 & $100 \mathrm{~S}_{36}$ \\
\hline RMSD & & 50.18 & 9.55 & & & \\
\hline
\end{tabular}

a3LYP/6-311++G(d,p) calculation; observed and calculated values in $\mathrm{cm}^{-1}$.

${ }^{\mathrm{b}}$ From scaled quantum mechanics force field (see text for further definition).

${ }^{\mathrm{c}}$ Units are $\mathrm{km} \mathrm{mol}^{-1}$.

${ }^{\mathrm{d}}$ Units are $\AA^{4} \mathrm{amu}^{-1}$.

ordinates take into account the local symmetry around the $\mathrm{C}$ and $\mathrm{S}$ atoms and follow the proposals of Fogarasi et al. ${ }^{33}$ The resulting force field was subsequently scaled using the scheme proposed by Pulay et al., ${ }^{35}$ and the initial scale factors were defined using unity for all modes, as shown in Table S12. ${ }^{20}$ These scale factors were subsequently refined by the nonlinear least-squares procedure to fit the experimental frequencies.

The refined scale factors corresponding to each force constant appear in Table S12, ${ }^{20}$ while the resulting frequencies, RMSD final value, and the potential-energy distribution are reported in Table VI. It can be seen that only half the modes have a participation of $\geq 50 \%$ of a single coordinate, whereas other modes represent very complex vibrations in which several coordinates are involved. The SQM force field
(Table S13) (Reg. 20) was used to calculate the internal force constants appearing in Table VII, which are in good agreement with the equivalent values for $\mathrm{CF}_{3} \mathrm{CO}_{2} \mathrm{CH}_{2} \mathrm{CH}_{3}$, $\mathrm{CF}_{3} \mathrm{CO}_{2} \mathrm{CH}_{2} \mathrm{CF}_{3}$ and $\mathrm{CF}_{3} \mathrm{SO}_{2} \mathrm{OCH}_{2} \mathrm{CH}_{3}$. ${ }^{50}$

\section{CONCLUSIONS}

The optimized molecular geometry and conformation for $S$-ethyl trifluorothioacetate have been calculated using MP2 and DFT calculations with different basis sets. At the B3LYP/6-311++G $(d, p)$ level the free energies for the two conformers show that the $C_{s}$-symmetric conformer was lower in energy than the $C_{1}$ conformer by approximately $2.6 \mathrm{~kJ} \mathrm{~mol}^{-1}$. NBO calculations have been performed in order to justify the preferred conformation of 
TABLE VII. Force constants in internal (valence) coordinates for $\mathrm{CF}_{3} \mathrm{COSCH}_{2} \mathrm{CH}_{3}$ and related molecules.

\begin{tabular}{|c|c|c|c|c|}
\hline Force constants ${ }^{\mathrm{a}}$ & $\mathrm{CF}_{3} \mathrm{COSCH}_{3} \mathrm{CH}_{2}{ }^{\mathrm{b}}$ & $\mathrm{CF}_{3} \mathrm{CO}_{2} \mathrm{CH}_{2} \mathrm{CH}_{3}^{\mathrm{c}}$ & $\mathrm{CF}_{3} \mathrm{CO}_{2} \mathrm{CH}_{2} \mathrm{CF}_{3}{ }^{\mathrm{d}}$ & $\mathrm{CF}_{3} \mathrm{SO}_{2} \mathrm{OCH}_{2} \mathrm{CH}_{3}{ }^{\mathrm{e}}$ \\
\hline$k_{\mathrm{f}}[\mathrm{C}(15)-\mathrm{F}]$ & 6.28 & 6.45 & 6.41 & 5.93 \\
\hline$k_{\mathrm{f}}[\mathrm{C}(15)-\mathrm{C} / \mathrm{S}(16)]$ & 3.49 & 3.86 & 3.91 & 3.11 \\
\hline$k_{\mathrm{f}}[\mathrm{C}(21)-\mathrm{C}(24)]$ & 4.30 & 4.67 & 4.53 & 4.27 \\
\hline$k_{\mathrm{f}}[\mathrm{C}=\mathrm{O}]$ & 12.49 & 13.13 & 13.43 & $\cdots$ \\
\hline$k_{\mathrm{f}}[\mathrm{C} / \mathrm{S}(16)-\mathrm{S} / \mathrm{O}(28)]$ & 2.97 & 6.42 & 6.22 & 5.04 \\
\hline$k_{\mathrm{f}}[\mathrm{S} / \mathrm{O}(28)-\mathrm{C}(21)]$ & 2.55 & 3.96 & 4.72 & 4.20 \\
\hline$k_{\mathrm{f}}[\mathrm{C}(21)-\mathrm{H}]$ & 4.88 & 4.88 & 5.00 & 4.90 \\
\hline$k_{\mathrm{f}}[\mathrm{C}(24)-\mathrm{H}]$ & 4.82 & 4.88 & $\cdots$ & 4.84 \\
\hline$k_{\mathrm{f}}[\mathrm{H}-\mathrm{C}(21)-\mathrm{H}]$ & 0.45 & 0.50 & 0.48 & 0.49 \\
\hline$k_{\mathrm{f}}[\mathrm{S} / \mathrm{O}(28)-\mathrm{C} / \mathrm{S}(16)=\mathrm{O}(20)]$ & 0.70 & 0.69 & 0.91 & 1.27 \\
\hline$k_{\mathrm{f}}[\mathrm{C}(15)-\mathrm{C} / \mathrm{S}(16)-\mathrm{S} / \mathrm{O}(28)]$ & 0.66 & 0.78 & 0.72 & 1.13 \\
\hline$k_{\mathrm{f}}[\mathrm{C}(15)-\mathrm{C} / \mathrm{S}(16)=\mathrm{O}(20)]$ & 0.70 & 0.67 & 0.67 & 1.04 \\
\hline$k_{\mathrm{f}}[\mathrm{C}-\mathrm{F} / \mathrm{C}-\mathrm{F}]$ & 0.91 & 0.93 & 0.75 & 0.72 \\
\hline
\end{tabular}

${ }^{\mathrm{a}}$ Units are mdyn $\AA^{-1}$ for stretches and stretch-stretch interactions and mdyn $\AA \mathrm{rad}^{-2}$ for angle bends.

${ }^{\mathrm{b}}$ This work.

${ }^{\mathrm{c}}$ Reference 5 .

${ }^{\mathrm{d}}$ Reference 6 .

${ }^{\mathrm{e}}$ Reference 50 .

$\mathrm{CF}_{3} \mathrm{COSCH}_{2} \mathrm{CH}_{3}$. We conclude that the electrostatic and steric contributions included in the Lewis term tend to promote the anti, anti conformer, whereas the delocalization contribution tends to favor the anti, gauche conformer, as expected from the anomeric effect.

IR and Raman spectra were recorded for $\mathrm{CF}_{3} \mathrm{COSCH}_{2} \mathrm{CH}_{3}$, for which 34 out of the expected 36 normal modes of vibration have been assigned. Both conformers were observed in the IR and Raman spectra. It was possible to scale the theoretical force field by taking the observed frequencies as a basis. The resulting SQM force field served to calculate the potential-energy distribution, which revealed the physical nature of the molecular vibrations. The force constants in internal coordinates were similar to those obtained earlier for related chemical species.

\section{ACKNOWLEDGMENTS}

We acknowledge the help of research grants from CIUNT (Consejo de Investigaciones de la Universidad Nacional de Tucumán) and CONICET (Consejo Nacional de Investigaciones Científicas y Técnicas) under Grant No. PIP 112-200801-00629. We thank the EPSRC for funding D.A.W. (Grant No. EP/F037317) and the NSCCS for computational resources.

${ }^{1}$ D. Xu, K. Prasad, A. Repic, and T. J. Blacklock, Tetrahedron Lett. 36, 41 (1995).

${ }^{2}$ E. E. Schallenberg and M. Calvin, J. Am. Chem. Soc. 77, 2779 (1955).

${ }^{3}$ N. S. True, C. J. Silvia, and R. K. Bohn, J. Phys. Chem. A 85, 1132 (1981).

${ }^{4}$ M. E. Defonsi Lestard, M. E. Tuttolomondo, E. L. Varetti, D. A. Wann, H. E. Robertson, D. W. H. Rankin, and A. Ben Altabef, "Gas-phase structure and new vibrational study of methyl trifluoroacetate, $\mathrm{CF}_{3} \mathrm{C}(\mathrm{O}) \mathrm{OCH}_{3}$," J. Raman Spectrosc. (in press).

${ }^{5}$ M. E. Defonsi Lestard, M. E. Tuttolomondo, E. L. Varetti, D. A. Wann, H. E. Robertson, D. W. H. Rankin, and A. Ben Altabef, "Experimental and theoretical structure and vibrational analysis of ethyl trifluoroacetate, $\mathrm{CF}_{3} \mathrm{CO}_{2} \mathrm{CH}_{2} \mathrm{CH}_{3}$," J. Raman Spectrosc. (in press).

${ }^{6}$ M. E. Defonsi Lestard, M. E. Tuttolomondo, E. L. Varetti, D. A. Wann, H. E. Robertson, D. W. H. Rankin, and A. Ben Altabef, J. Mol. Struct. 917, 183 (2009).
${ }^{7}$ W. Yang and D. G. Drueckhammer, J. Am. Chem. Soc. 123, 11004 (2001).

${ }^{8}$ S. E. Ulic, C. O. Della Védova, A. Hermann, H.-G. Mack, and H. Oberhammer, Inorg. Chem. 41, 5699 (2002).

${ }^{9}$ Q. Shen and K. Hagen, J. Mol. Struct. 128, 41 (1985).

${ }^{10}$ R. M. Romano, C. O. Della Védova, A. J. Downs, H. Oberhammer, and S. Parsons, J. Am. Chem. Soc. 123, 12623 (2001).

${ }^{11}$ H.-G. Mack, H. Oberhammer, and C. O. Della Védova, J. Phys. Chem. 95, 4238 (1991).

${ }^{12}$ H.-G. Mack, C. O. Della Védova, and H. Oberhammer, J. Phys. Chem. 96, 9215 (1992).

${ }^{13}$ S. E. Ulic, A. Kosma, C. O. Della Védova, H. Willner, and H. Oberhammer, J. Phys. Chem. 110, 10201 (2006).

${ }^{14}$ M. F. Erben, C. O. Della Védova, H.-G. Mack, H. Oberhammer, and R. Boese, Inorg. Chem. 44, 7070 (2005).

${ }^{15}$ A. Hermann, S. E. Ulic, C. O. Della Védova, H. Willner, and H. Oberhammer, J. Fluorine Chem. 112, 297 (2001).

${ }^{16}$ C. M. Huntley, G. S. Laurenson, and D. W. H. Rankin, J. Chem. Soc. Dalton Trans. 1980, 954.

${ }^{17}$ H. Fleischer, D. A. Wann, S. L. Hinchley, K. B. Borisenko, J. R. Lewis, R. J. Mawhorter, H. E. Robertson, and D. W. H. Rankin, J. Chem. Soc. Dalton Trans. 2005, 3221.

${ }^{18}$ S. L. Hinchley, H. E. Robertson, K. B. Borisenko, A. R. Turner, B. F. Johnston, D. W. H. Rankin, M. Ahmadian, J. N. Jones, and A. H. Cowley, J. Chem. Soc. Dalton Trans. 2004, 2469.

${ }^{19}$ A. W. Ross, M. Fink, and R. Hilderbrandt, International Tables for Crystallography, edited by A. J. C. Wilson (Kluwer Academic, Dordrecht, 1992), Vol. C, p. 245.

${ }^{20}$ See EPAPS supplementary material at http://dx.doi.org/10.1063/ 1.3267633 for experimental parameters from the GED refinement, RMSDs between experimental (GED) and calculated geometry data of $C_{1}$ and $C_{\mathrm{s}}$ conformers, contributions of Lewis energy hyperconjugation energy, important hyperconjugative interactions, electrostatic contributions to the energies, energies and occupancies of the NBOs, refined and calculated amplitudes of vibration and associated correction values GED refinement, least-squares correlation matrix, GED-determined coordinates, calculated coordinates, definition of natural internal coordinates, scale factors for the force field, SQM force constant matrix, dependence of the relative total energy on the CSCC rotation angle, dependence of attractive and repulsive energy increments on the CSCC dihedral angle, and molecular-scattering intensity curves.

${ }^{21}$ National Service for Computational Chemistry Software (NSCCS), URL: http://www.nsccs.ac.uk.

${ }^{22}$ M. J. Frisch, G. W. Trucks, H. B. Schlegel et al., GAussian 03, Revision C.02, Gaussian, Inc., Wallingford CT, 2004.

${ }^{23}$ C. Møller and M. S. Plesset, Phys. Rev. 46, 618 (1934).

${ }^{24}$ R. Krishnan, J. S. Binkley, R. Seeger, and J. A. Pople, J. Chem. Phys. 72, 650 (1980). 
${ }^{25}$ A. D. McLean and G. S. Chandler, J. Chem. Phys. 72, 5639 (1980).

${ }^{26}$ M. J. Frisch, J. A. Pople, and J. S. Binkley, J. Chem. Phys. 80, 3265 (1984).

${ }^{27}$ W. J. Hehre, P. R. Schleyer, and J. A. Pople, Ab Initio Molecular Orbital Theory (Wiley, New York, 1986).

${ }^{28}$ A. D. Becke, J. Chem. Phys. 98, 5648 (1993).

${ }^{29}$ C. Lee, W. Yang, and R. G. Parr, Phys. Rev. B 37, 785 (1988).

${ }^{30}$ J. P. Perdew, K. Burke, and M. Ernzerhof, Phys. Rev. Lett. 77, 3865 (1996); 78, 1396(E) (1997).

${ }^{31}$ V. A. Sipachev, J. Mol. Struct.: THEOCHEM 121, 143 (1985); J. Mol. Struct. 567-568, 67 (2001).

${ }^{32}$ E. D. Glendening, J. K. Badenhoop, A. D. Reed, J. E. Carpenter, and F. F. Weinhold, Theoretical Chemistry Institute (University of Wisconsin, Madison, WI, 1996)

${ }^{33}$ G. Fogarasi, X. Zhou, P. W. Taylor, and P. Pulay, J. Am. Chem. Soc. 114, 8191 (1992).

${ }^{34}$ E. B. Wilson, J. C. Decius, and P. C. Cross, Molecular Vibrations (McGraw-Hill, New York, 1955).

${ }^{35}$ P. Pulay, G. Fogarasi, G. Pongor, J. E. Boggs, and A. Braga, J. Am. Chem. Soc. 105, 7037 (1983).

${ }^{36}$ W. B. Collier, Program FCARTP (QCPE \#631), Department of Chemistry, Oral Roberts University, Tulsa, OK (1992).

${ }^{37}$ B. Nielsen and A. J. Holder, Gaussview, User's Reference, Gaussian, Inc., Pittsburgh, PA (1997).

${ }^{38}$ M. E. Tuttolomondo, A. Navarro, T. Peña Ruiz, E. L. Varetti, S. A.
Hayes, D. A. Wann, H. E. Robertson, D. W. H. Rankin, and A. Ben Altabef, J. Phys. Chem. A 111, 9952 (2007).

${ }^{39}$ J. L. Duncan, Mol. Phys. 28, 1177 (1974).

${ }^{40}$ S. Millefiori and A. Alparone, J. Chem. Soc., Faraday Trans. 94, 25 (1998).

${ }^{41}$ L. Radom, W. J. Hehre, and J. A. Pople, J. Am. Chem. Soc. 94, 2371 (1972).

${ }^{42}$ L. Radom and J. A. Pople, J. Am. Chem. Soc. 92, 4786 (1970).

${ }^{43}$ A. J. Blake, P. T. Brain, H. McNab, J. Miller, C. A. Morrison, S. Parsons, D. W. H. Rankin, H. E. Robertson, and B. A. Smart, J. Phys. Chem. 100, 12280 (1996); P. T. Brain, C. A. Morrison, S. Parsons, and D. W. H. Rankin, J. Chem. Soc. Dalton Trans. 1996, 4589; N. W. Mitzel and D. W. H. Rankin, ibid. 2003, 3650

${ }^{44}$ W. C. Hamilton, Acta Crystallogr. 18, 502 (1965).

${ }^{45}$ M. F. Erben, R. Boese, C. O. Della Védova, H. Oberhammer, and H. Willner, J. Org. Chem. 71, 616 (2006).

${ }^{46}$ K. I. Gobbato, C. O. Della Védova, H. G. Mack, and H. Oberhammer, Inorg. Chem. 35, 6152 (1996).

${ }^{47}$ S. E. Ulic, E. M. Coyanis, R. M. Romano, and C. O. Della Védova, Spectrochim. Acta, Part A 54, 695 (1998).

${ }^{48}$ P. I. Nagy, F. R. Tejada, J. G. Sarver, and W. S. Messer, J. Phys. Chem. A 108, 10173 (2004).

${ }^{49}$ B. J. Lynch and D. G. Truhlar, J. Phys. Chem. A 105, 2936 (2001).

${ }^{50}$ M. E. Tuttolomondo, A. Navarro, E. L. Varetti, and A. Ben Altabef, J. Raman Spectrosc. 36, 427 (2005). 